\title{
Natural Polyphenols for Prevention and Treatment of Cancer
}

\author{
Yue Zhou ${ }^{1}$, Jie Zheng ${ }^{1}$, Ya Li ${ }^{1}$, Dong-Ping $\mathrm{Xu}^{1}{ }^{1}$, Sha $\mathrm{Li}^{2}$, Yu-Ming Chen ${ }^{1}$ and Hua-Bin $\mathrm{Li}{ }^{1,3, *}$ \\ 1 Guangdong Provincial Key Laboratory of Food, Nutrition and Health, School of Public Health, \\ Sun Yat-sen University, Guangzhou 510080, China; zhouyue3@mail2.sysu.edu.cn (Y.Z.); \\ zhengj37@mail2.sysu.edu.cn (J.Z.); liya28@mail2.sysu.edu.cn (Y.L.); xudp@mail2.sysu.edu.cn (D.-P.X.); \\ chenyum@mail.sysu.edu.cn (Y.-M.C.) \\ 2 School of Chinese Medicine, The University of Hong Kong, Hong Kong, China; u3003781@connect.hku.hk \\ 3 South China Sea Bioresource Exploitation and Utilization Collaborative Innovation Center, \\ Sun Yat-sen University, Guangzhou 510006, China \\ * Correspondence: lihuabin@mail.sysu.edu.cn; Tel.: +86-20-8733-2391
}

Received: 15 June 2016; Accepted: 12 August 2016; Published: 22 August 2016

\begin{abstract}
There is much epidemiological evidence that a diet rich in fruits and vegetables could lower the risk of certain cancers. The effect has been attributed, in part, to natural polyphenols. Besides, numerous studies have demonstrated that natural polyphenols could be used for the prevention and treatment of cancer. Potential mechanisms included antioxidant, anti-inflammation as well as the modulation of multiple molecular events involved in carcinogenesis. The current review summarized the anticancer efficacy of major polyphenol classes (flavonoids, phenolic acids, lignans and stilbenes) and discussed the potential mechanisms of action, which were based on epidemiological, in vitro, in vivo and clinical studies within the past five years.
\end{abstract}

Keywords: polyphenol; flavonoid; anticancer; antioxidant; anti-inflammation

\section{Introduction}

Globally, there were approximately 14.1 million new cancer cases in 2012, and the number was estimated to reach 25 million in 2032. Aside from the high incidence, cancer is also one of the leading causes of death. In 2012 alone, there were about 8.2 million cancer-related deaths, which were mainly attributed to lung, gastric, colorectal, liver, breast, prostate and cervical cancer [1]. The situation urges the research of cancer prevention and treatment. In the last two decades, the anticancer effects of natural polyphenols have become a hot topic in many laboratories. Meanwhile, polyphenols are potential candidates for the discovery of anticancer drugs. Polyphenols are defined as compounds having at least one aromatic ring with one or more hydroxyl functional groups attached. Natural polyphenols refer to a large group of plant secondary metabolites ranging from small molecules to highly polymerized compounds [2]. Polyphenols are widely present in foods and beverages of plant origins (e.g., fruits, vegetables, spices, soy, nuts, tea and wine) [3-5]. Based on chemical structures, natural polyphenols can be divided into five classes, including flavonoids, phenolic acids, lignans, stilbenes and other polyphenols. Flavonoids and phenolic acids are the most common classes, and account for about $60 \%$ and $30 \%$ of all natural polyphenols, respectively (Table 1) [6]. A plethora of studies have documented the anticancer effects of natural polyphenols [7-11]. Noteworthy examples include anthocyanins from blueberries, epigallocatechin gallate (EGCG) from green tea, resveratrol from red wine and isoflavones from soy. The anticancer efficacy of natural polyphenols has largely been attributed to their potent antioxidant and anti-inflammatory activities as well as their abilities to modulate molecular targets and signaling pathways, which were associated with cell survival, proliferation, differentiation, migration, angiogenesis, hormone activities, detoxification enzymes, immune responses, etc. [12,13]. 
The present review summarized recent discoveries about the anti-carcinogenic properties of natural polyphenols and discussed the mechanisms of action, which were based on evidence from epidemiological studies, laboratory experiments and clinical trials.

Table 1. The classification of natural polyphenols.

\begin{tabular}{|c|c|c|c|}
\hline \multicolumn{2}{|c|}{ Classification } & Representative Members & Major Dietary Sources \\
\hline \multirow{6}{*}{ flavonoids } & anthocyanins & $\begin{array}{l}\text { delphinidin, pelargonidin, } \\
\text { cyanidin, malvidin }\end{array}$ & $\begin{array}{l}\text { berries, grapes, cherries, } \\
\text { plums, pomegranates }\end{array}$ \\
\hline & flavanols & $\begin{array}{l}\text { epicatechin, epigallocatechin, } \\
\text { EGCG, procyanidins }\end{array}$ & $\begin{array}{l}\text { apples, pears, legumes, tea, } \\
\text { cocoa, wine }\end{array}$ \\
\hline & flavanones & hesperidin, naringenin & citrus fruits \\
\hline & flavones & apigenin, chrysin, luteolin, & $\begin{array}{l}\text { parsley, celery, orange, } \\
\text { onions, tea, honey, spices }\end{array}$ \\
\hline & flavonols & $\begin{array}{l}\text { quercetin, kaempferol, myricetin, } \\
\text { isorhamnetin, galangin }\end{array}$ & $\begin{array}{l}\text { berries, apples, broccoli, } \\
\text { beans, tea }\end{array}$ \\
\hline & isoflavonoids & genistein, daidzein & soy \\
\hline \multirow[t]{2}{*}{ phenolic acids } & hydroxybenoic acid & ellagic acid, gallic acid & $\begin{array}{l}\text { pomegranate, grapes, } \\
\text { berries, walnuts, chocolate, } \\
\text { wine, green tea }\end{array}$ \\
\hline & hydroxycinnamic acid & ferulic acid, chlorogenic acid & coffee, cereal grains \\
\hline \multicolumn{2}{|c|}{ lignans } & $\begin{array}{l}\text { sesamin, secoisolariciresinol } \\
\text { diglucoside }\end{array}$ & flaxseeds, sesame \\
\hline \multicolumn{2}{|c|}{ stilbenes } & $\begin{array}{l}\text { resveratrol, pterostilbene, } \\
\text { piceatannol }\end{array}$ & grapes, berries, red wine \\
\hline
\end{tabular}

\section{Epidemiological Studies}

Evidence from epidemiological studies is inconsistent, especially when considering the results of prospective cohort studies (Table 2). A case-control study in Canada reported favorable effects of a high dietary intake of total flavonoids on lung cancer risks [14]. Apart from this, in a Korean study, for women, the intake of total flavonoids, as well as flavones and anthocyanidins, was inversely associated with the risk of gastric cancer [15]. However, another study in America found no significant association between flavonoids intake and the incidence or survival of gastric cancer [16]. For colorectal cancer, a meta-analysis showed protective roles of high dietary isoflavone intake [17]. Besides, a Spanish case-control study suggested that the dietary intake of total flavonoids (especially certain subclasses) and lignans might decrease colorectal cancer risks [18]. However, large prospective cohorts showed that high habitual consumption of flavonoids could not protect against colorectal cancer [19]. In addition, the Fukuoka study reported no association between total dietary polyphenols and colorectal cancer risks [20]. For hepatocellular carcinoma (HCC), the European Prospective Investigation into Cancer and Nutrition suggested that a high intake of dietary flavanols, but not total flavonoids, might modestly decrease HCC risks [21,22]. In addition, according to a meta-analysis, the risk of breast cancer was reduced in women with a high intake of flavonols and flavones [23]. Studies also suggested that soy isoflavone intake reduced breast cancer risk for Asian women, which was more potent for post-menopausal women (OR $0.46,95 \%$ CI 0.28-0.78) than for premenopausal women (OR 0.63 , 95\% CI 0.50-0.80). However, for women in Western countries, no significant association could be found, which might due to low levels of isoflavone consumption in the Western population [24,25]. In addition, the estrogen receptor (ER) status might modify the association. For example, a U.S. prospective cohort study showed that a modest inverse trend existed for dietary flavanols intake and the risk of ER-negative breast cancer, but not ER-positive cancer [26]. For prostate cancer, data from a Netherlands cohort study showed that dietary flavonoid intake was correlated with decreased risks of advanced stage prostate cancer but not overall or non-advanced prostate cancer [27]. On the contrary, in a prospective cohort study, the intake of total flavonoids as well as flavan-3-ols, isoflavones, and proanthocyanidins, increased prostate cancer risks [28]. 
It should be noted that the assessment of polyphenol intakes in many epidemiological studies was based on food questionnaires, which could not provide the exact composition of foods. Therefore, it might be difficult for them to reflect the real impact of natural polyphenols on cancer. In this case, the experimental study in cell culture or animal modes might be a more direct way to assess the anticancer efficacy of natural polyphenols as well as to examine the possible mechanisms involved in this process.

Table 2. Dietary polyphenol intake and cancer risks.

\begin{tabular}{|c|c|c|c|c|}
\hline Cancer & Polyphenols & Study Type & Risk Estimates (95\% CI) & References \\
\hline lung cancer & flavonoids & case-control study & $0.63(0.47-0.85)$ & [14] \\
\hline \multirow{2}{*}{ gastric cancer } & flavonoids & case-control study & no significant association & [16] \\
\hline & flavonoids & case-control study & $0.33(0.15-0.73)$ & [15] \\
\hline \multirow{4}{*}{ colorectal cancer } & flavonoids & cohort study & no significant association & [19] \\
\hline & $\begin{array}{l}\text { flavonoids and } \\
\text { lignans }\end{array}$ & case-control study & $\begin{array}{l}\text { total flavonoids } 0.59(0.35-0.99) \\
\text { lignans } 0.59(0.34-0.99)\end{array}$ & [18] \\
\hline & polyphenols & case-control study & no significant association & [20] \\
\hline & isoflavones & meta-analysis & $0.76(0.59-0.98)$ & [17] \\
\hline $\mathrm{HCC}$ & flavanols & cohort study & $0.62(0.33-0.99)$ & [22] \\
\hline \multirow[t]{3}{*}{ breast cancer } & flavonoids & meta-analysis & $\begin{array}{l}\text { flavonols } 0.88(0.80-0.98) ; \\
\text { flavones } 0.83(0.76-0.91) ; \\
\text { no significant association for total } \\
\text { flavonoids or other subclasses }\end{array}$ & [23] \\
\hline & isoflavones & meta-analysis & $0.68(0.52-0.89)$ & [25] \\
\hline & flavanols & cohort study & $0.81(0.67-0.97)$ & [26] \\
\hline \multirow[b]{2}{*}{ prostate cancer } & flavonoids & cohort study & $1.15(1.04-1.27)$ & [28] \\
\hline & flavonoids & cohort study & $\begin{array}{l}\text { total catechin } 0.73(0.57-0.95) \text {; } \\
\text { epicatechin } 0.74(0.57-0.95) ; \\
\text { kaempferol } 0.78(0.61-1.00) \text {; } \\
\text { myricetin } 0.71(0.55-0.91)\end{array}$ & [27] \\
\hline
\end{tabular}

\section{Experimental Studies}

Accumulating evidence from laboratory studies has supported the anticancer properties of natural polyphenols. Given the vast number of studies, a search of PubMed and Web of Science was conducted to identify relevant peer-reviewed articles published in English within 5 years.

\subsection{Anthocyanins}

Anthocyanins (Figure 1), which occur ubiquitously throughout the plant kingdom, are the basis for the bright attractive red, blue and purple colors of fruits and vegetables. In plants, anthocyanins are usually glycosylated with glucose, galactose, arabinose, rutinose, etc. The aglycone forms are known as anthocyanidin, including cyanidin, delphinidin, peonidin, petunidin, pelargonidin, and malvidin [29].<smiles></smiles>

Figure 1. The chemical structures of cyanidin $\left(R_{1}=O H, R_{2}=H\right)$, delphinidin $\left(R_{1}=R_{2}=O H\right)$, peonidin $\left(\mathrm{R}_{1}=\mathrm{OCH} 3, \mathrm{R}_{2}=\mathrm{H}\right)$, petunidin $\left(\mathrm{R}_{1}=\mathrm{OCH} 3, \mathrm{R}_{2}=\mathrm{OH}\right)$, pelargonidin $\left(\mathrm{R}_{1}=\mathrm{R}_{2}=\mathrm{H}\right)$ and malvidin $\left(\mathrm{R}_{1}=\mathrm{R}_{2}=\mathrm{OCH} 3\right)$. 
Among anthocyanins, delphinidin possesses strong anticancer activities. Studies have shown that delphinidin treatment induced apoptosis and cell cycle arrest in several types of cancer. This effect might be due to suppression of the NF-kB pathway [30,31]. The over-expression of human epidermal growth factor receptor 2 (HER2) is usually associated with poor prognosis. A study found that two anthocyanins extracted from black rice, peonidin-3-glucoside and cyaniding-3-glucoside, could induce apoptosis and selectively decrease cell proliferation and tumor growth of HER2 positive breast cancer [32]. In addition, peonidin-3-glucoside treatment significantly suppressed invasion and metastasis of lung cancer cells by down-regulating the matrix metalloproteinase (MMP) [33]. In similar ways, cyanidin-3-O-sambubioside from Acanthopanax sessiliflorus fruit inhibited angiogenesis and invasion of breast cancer cells [34]. Though anthocyanins are usually considered as antioxidants, a study showed that certain anthocyanins (cyanidin and delphinidin) exhibited oxidative stress-based cytotoxicity to colorectal cancer cells [35]. Another study evaluated the impact of chemical structures on chemopreventive activities of anthocyanins in colon cancer cells. Data indicated that nonacylated monoglycosylated anthocyanins were more potent in inhibiting cancer cell growth, while anthocyanins with pelargonidin aglycone and triglycosylation were weak [36]. On the other hand, it was suggested that a mixture of different anthocyanins might be better than a single one in cancer treatment. For example, a combination of sub-optimal concentration of anthocyanidins synergistically suppressed the growth of lung cancer cells. Meanwhile, in a mice model of lung cancer, a mixture of anthocyanidins from bilberry $(0.5 \mathrm{mg} /$ mouse) or delphinidin $(1.5 \mathrm{mg} /$ mouse $)$ all inhibited tumor growth, and the effective concentration of delphinidin in the mixture was eight-fold lower than the purified compound [7].

\subsection{Xanthohumol}

Xanthohumol (Figure 2) is a major prenylated chalcone isolated from hops (Humulus lupulus). The compound can also be found in beer, but to a much less extent. In some cancers, the xanthohumol-induced cell death was accompanied by apoptosis and S phase cell cycle arrest $[37,38]$. A study suggested that the apoptosis induced by treatment of xanthohumol (10-40 $\mu \mathrm{M})$ to HepG2 liver cancer cells was due to modulation of the NF- $\mathrm{BB} / \mathrm{p} 53$ signaling pathway [39]. Another study reported that xanthohumol treatment $(>5 \mu \mathrm{M})$ mediated anticancer activity in human liver cancer cells through suppression of the Notch1 signaling pathway [40]. In addition, xanthohumol could block the estrogen signaling pathway. By doing so, it selectively suppressed the growth of ER $\alpha$-positive breast cancer both in vitro and in vivo [41]. Cysteine X Cysteine chemokine receptor 4 (CXCR4) is over-expressed in many cancers and mediates metastasis of cancer cells to sites expressing its cognate ligand CXCL12. A study demonstrated that xanthohumol treatment dose- and time-dependently decreased expression of CXCR4, thus inhibiting cell invasion induced by CXCL12 in breast and colon cancer cells [42]. In another study, by promoting production of reactive oxygen species (ROS), xanthohumol treatment inhibited the progression of advanced tumor and the growth of poorly differentiated prostate cancer in the transgenic mice [43].<smiles>COc1cc(O)c(CC=C(C)C)c(O)c1C(=O)/C=C/c1ccc(O)cc1</smiles>

Figure 2. The chemical structure of xanthohumol. 


\subsection{Flavanols}

Flavanols, also known as flavan-3-ols, have the most complex structures among subclasses of flavonoid. Flavanols include simple monomers (catechins) as well as oligomers and polymers, the latter two are known as proanthocyanidins or condensed tannins. Flavanols can be commonly found in foodstuffs [29].

\subsubsection{EGCG}

Smoking is a well-established risk factor of lung cancer. A study showed that EGCG (Figure 3) treatment suppressed nicotine-induced migration and invasion of A549 lung cancer cells in vitro as well as in mice through inhibiting angiogenesis and epithelial-mesenchymal transition (EMT) [9]. The effects of EGCG varied with dose. In CL1-5 lung cancer cells, at concentration of 5-20 $\mu \mathrm{M}$, EGCG effectively suppressed the invasion and migration through suppressing MMP-2 expression. While at higher concentration $(>20 \mu \mathrm{M})$, it exhibited anti-proliferation activities through induction of $\mathrm{G}_{2} / \mathrm{M}$ cell cycle arrest but not apoptosis [44]. Another study found that several gastric cancer cell lines were sensitive to EGCG $(100 \mu \mathrm{M})$ induced apoptosis due to inhibition of survivin, a potent anti-apoptotic protein [45]. Many signaling pathways might be affected by EGCG treatment. A study showed that EGCG $(20 \mu \mathrm{M})$ exerted anti-proliferative effects in gastric cancer cell by preventing the $\beta$-catenin oncogenic signaling pathway [46]. Another study on colon cancer suggested that the Akt, extracellular signal-related kinase (ERK) $1 / 2$ and alternative p38MAPK signaling pathways were involved in the chemopreventive effects of EGCG [47]. Besides, there is a growing interest in cancer epigenetics in recent years mainly due to the reversibility of epigenetic alterations. Major epigenetic alterations involve DNA methylation, histone modifications and miRNAs [48]. The combination of EGCG and sodium butyrate inhibited DNA methytransferases and class I histone deacetylases (HDACs) in colorectal cancer cells, thus modulating global DNA methylation and histone modifications [49]. In addition, the cancer stem cell plays a key role in chemoresistance and recurrence. Both in vitro and in vivo studies showed that EGCG could suppress cancer stem cell growth of colorectal cancer as well as breast cancer [50,51]. The anticancer activities of EGCG might involve modulation of hormone activities. It is known that exposure to estrogen is an important risk factor of breast cancer. A study found that EGCG $(1 \mu \mathrm{M})$ could suppress estrogen (estradiol, E2)-induced breast cancer cell proliferation [52]. In addition, EGCG treatment down-regulated $\mathrm{ER} \alpha$ in $\mathrm{ER}^{+} / \mathrm{PR}^{+}$breast cancer cells [53]. Treatment of EGCG $(20 \mu \mathrm{M})$ also inhibited metastasis of breast cancer cells by restoring the balance between MMP and the tissue inhibitor of matrix metalloproteinase (TIMP). Mechanistic studies suggested that the epigenetic induction of TIMP-3 was a key event in this process, which involved modifying the enhancer of zeste homolog 2 and HDAC1 [54]. Androgen deprivation is a main therapy for prostate cancer. It was reported that EGCG could functionally antagonize androgen, leading to suppression of prostate cancer growth both in vitro and in vivo [55].

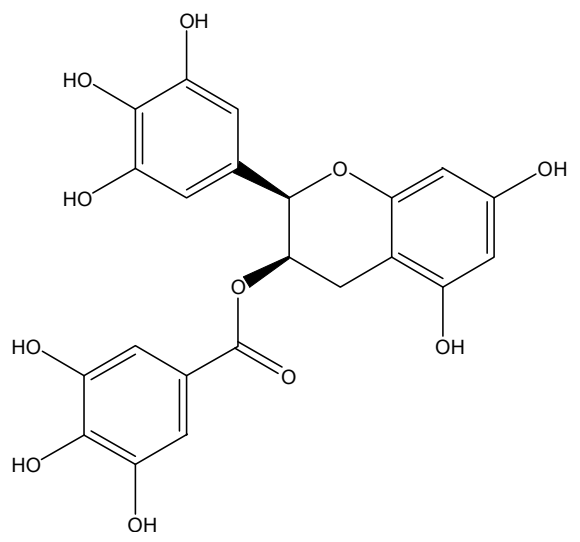

Figure 3. The chemical structure of EGCG. 


\subsubsection{Procyanidins}

A study suggested that procyanidin $\mathrm{C} 1$ from Cinnamomi cortex might be able to prevent TGF- $\beta$-induced EMT in the A549 lung cancer cells [56]. Another study found that hexmer form of procyanidins from cocoa inhibited the proliferation $(50$ and $100 \mu \mathrm{M})$, induced apoptosis and $\mathrm{G}_{2} / \mathrm{M}$ cell cycle arrest in several colorectal cancer cells, which was possibly mediated by the Akt pathway [57]. Procyanidins from Japanese quince also showed pro-apoptotic effects on Caco-2 colon cancer cells, with the oligomer enriched extract showing a more potent pro-apoptotic activity [58]. Besides, data shows that in breast cancer cells, treatment of procyanidins from evening primrose $(25-100 \mu \mathrm{M}$ gallic acid equivalents) decreased cell viability by promoting apoptosis and reduced cell invasion by suppressing angiogenesis propensity [59].

\subsection{Flavanones}

Flavanones (Figure 4) are abundant in citrus fruits, especially the solid parts of fruit. Major flavanones are naringenin from grapefruit and hesperetin from oranges [2].

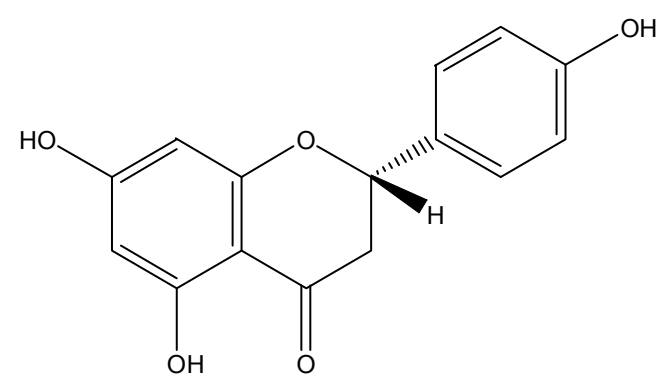

(a)

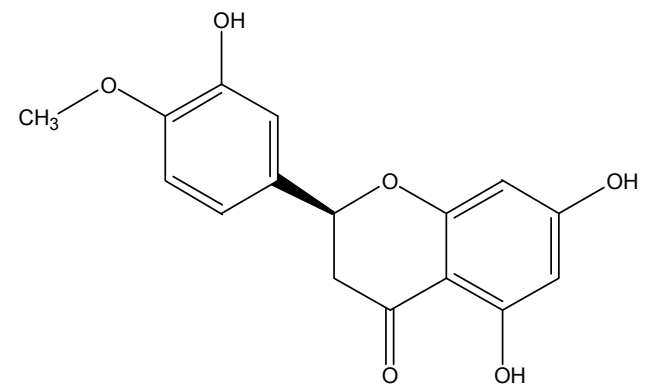

(b)

Figure 4. The chemical structures of naringenin (a) and hesperetin (b).

\subsubsection{Naringenin}

In A549 lung cancer cells, naringenin treatment enhanced TRAIL-mediated apoptosis by up-regulating the expression of death receptor 5 [60]. Besides, in SGC-7901 gastric cancer cells, naringenin treatment inhibited cancer cell proliferation, invasion, and migration and induced apoptosis, which might be related to its inhibition of the Akt signaling pathway [61]. Another study in colon cancer cells suggested that the pro-apoptotic activity of naringenin was mediated by the p38-dependent pathway [62]. In HCC cells, naringenin could suppress TPA-induced cancer cell invasion by down-regulating multiple signaling pathways, such as the NF- $\mathrm{KB}$ pathway, the ERK and c-Jun N-terminal kinase (JNK) signaling pathway [63]. Besides, naringenin treatment to HepG2 liver cancer cells induced mitochondrial-mediated apoptosis and cell cycle arrest through up-regulation of p53 [64]. In breast cancer cells, naringenin demonstrated anti-estrogenic activity in estrogen-rich status and estrogenic activity in estrogen-deficient status [65]. In addition, oral administration of naringenin suppressed breast cancer metastases after surgery by modulating the host immunity [66].

\subsubsection{Hesperetin}

In gastric cancer cells, hesperetin treatment $(100-400 \mu \mathrm{M})$ decreased cell proliferation and induced mitochondria-mediated apoptosis via promoting intracellular ROS accumulation. Meanwhile, the compound (i.p. $20-40 \mathrm{mg} / \mathrm{kg}$ thrice a week) significantly suppressed the growth of xenograft tumors in mice model of gastric cancer [67]. Besides, dietary hesperetin showed anti-proliferative activities against chemical-induced colon carcinogenesis. Oral supplements of hesperetin $(20 \mathrm{mg} / \mathrm{kg} / \mathrm{day})$ reduced the proliferating cell nuclear antigen, the formation of aberrant crypt foci induced by 1,2-dimethylhydrazine in rat [68]. In breast cancer cells, hesperetin $(40-200 \mu \mathrm{M})$ induced growth 
inhibition also involved mitochondria-mediated apoptosis, increased ROS and activation of ASK1/JNK pathway [69]. Cancer cells usually have high levels of glucose uptake and metabolism, which plays an important role in tumor growth. A study suggested that the anti-proliferative effects of hesperetin $(50-100 \mu \mathrm{M})$ on breast cancer were possibly due to the suppression of glucose uptake [70]. Another study found that hesperetin treatment $\left(\mathrm{IC}_{50} 40-90 \mu \mathrm{M}\right)$ decreased proliferation and induced apoptosis in PC-3 prostate cancer cells, which was likely mediated by inhibition of the NF- $\mathrm{kB}$ pathway [71]. In addition, hesperetin $\left(\mathrm{IC}_{50} 650 \mu \mathrm{M}\right)$ exhibited potential anticancer effects on cervical cancer cells through the induction of both extrinsic and intrinsic apoptosis [72].

\subsection{Flavones}

Flavones (Figure 5) in food are usually the glycosides of apigenin and luteolin. Important dietary sources of flavones are parsley and celery [2].<smiles>[R6]c1cc(-c2cc(=O)c3c(O)cc(O)cc3o2)ccc1Br</smiles>

Figure 5. The chemical structures of apigenin $\left(R_{1}=O H, R_{2}=H\right)$, chrysin $\left(R_{1}=R_{2}=H\right)$ and luteolin $\left(\mathrm{R}_{1}=\mathrm{R}_{2}=\mathrm{OH}\right)$.

\subsubsection{Apigenin}

Apigenin is a common flavonoid widely distributed in plant-based food, such as orange, parsley, onions, tea and wheat sprouts [73]. In H460 lung cancer cells, treatment of apigenin (40-160 $\mu \mathrm{M})$ induced apoptosis and DNA damage, which was accompanied by increased production of ROS and $\mathrm{Ca}^{2+}$ as well as a change of the Bax/Bcl-2 ratio [74]. Apigenin $(20 \mu \mathrm{g} / \mathrm{mL})$ also induced apoptosis in gastric cancer cells, especially in the undifferentiated gastric cancer cells, while showed little cytotoxicity to normal gastric cells [75]. Helicobacter pylori infection is known to cause ulcers and is possibly linked to gastric cancer. Atrophic gastritis was suggested to be a critical step in Helicobacter pylori-induced carcinogenesis. A study found that apigenin administration (30-60 mg/kg/week) could prevent Helicobacter pylori-induced atrophic gastritis as well as gastric cancer development in Mongolian gerbils [76]. Additionally, apigenin treatment $(20-120 \mu \mathrm{M})$ suppressed proliferation, invasion and migration of several colorectal cancer cell lines. The compound $(50 \mathrm{mg} / \mathrm{kg})$ also inhibited tumor growth and metastasis in the orthotopic colorectal cancer model [77].

About $20 \%$ of breast cancer cases are HER2-positive, with amplification of human epidermal growth factor receptor (HER2) or over-expression of HER2 protein. These cancers are usually more aggressive and more resistant to hormone treatment than other types of breast cancer. A study found that apigenin treatment $(20-100 \mu \mathrm{M})$ significantly suppressed growth and caused apoptosis in HER2-positive breast cancer cells, which was possibly mediated by inhibition of the signal transducer and activator of transcription 3 (STAT3) signaling pathway [78]. Another study reported anticancer effects of apigenin on MDA-MB-231 breast cancer cells in vitro $(10-40 \mu \mathrm{M})$ and in vivo $(5$ and $25 \mathrm{mg} / \mathrm{kg}$ ). Possible mechanisms included induction of $\mathrm{G}_{2} / \mathrm{M}$ cell cycle arrest and epigenetic alterations. Apigenin inhibited HDACs, which induced acetylation of histone H3 in the p21 WAF1/CIP1 promoter region, leading to enhanced transcription of p21 WAF1/CIP1 [79]. Similar epigenetic effects were also found in prostate cancer. Apigenin inhibited HDACs, especially HDAC1 and HDAC3 expression. In this way apigenin treatment $(20-40 \mu \mathrm{M})$ induced cell cycle arrest and apoptosis in prostate cancer cells and markedly inhibited tumor growth in mice (oral administration: 20 and 
$50 \mu \mathrm{g} / \mathrm{mouse} /$ day) [80]. In addition, apigenin treatment to mice (20 and $50 \mu \mathrm{g} / \mathrm{mouse} /$ day) markedly decreased tumor volumes of the prostate, inhibited angiogenesis and completely prevented distant organ metastasis, which at least in part, was mediated by the PI3K/Akt/Forkhead box O (FoxO) signaling pathway [81].

\subsubsection{Chrysin}

Chrysin is a naturally occurring flavone present in honey and propolis as well as the passion flower (Passiflora caerulea), and has displayed a variety of bioactivities, such as antioxidant, anti-inflammatory and anticancer activities [82]. AMPK activation is associated with cancer cell apoptosis. A study suggested that AMPK activation might be involved in the growth inhibition and apoptosis induced by chrysin treatment $(10 \mu \mathrm{M})$ in lung cancer cells, and ROS might be a key regulator in this process [83]. Chrysin $(50-100 \mu \mathrm{M})$ also exhibited chemopreventive effects in colorectal cancer cells, mainly as a result of TNF-mediated apoptotic cell death, and the aryl hydrocarbon receptor, a transcriptional factor, seemed to modulate this process [84]. Besides, in human triple-negative breast cancer cells, chrysin treatment $(5,10$ and $20 \mu \mathrm{M})$ dose-dependently inhibited the potential of cancer cells to invasion and migration by down-regulating MMP-10, EMT and the PI3K/Akt signaling pathway [82].

\subsubsection{Luteolin}

Luteolin is abundant in artichoke as well as several spices, including sage, thyme and oregano. In A549 lung cancer cells, luteolin exhibited significant cytotoxic effects ( IC $_{50} 40.2 \mu \mathrm{M}$ ) through induction of $G_{2}$ cell cycle arrest and apoptosis. The apoptosis was induced in a mitochondria-dependent pathway and was associated with activation of JNK and inhibition of NF-kB (p65) translocation [85]. The micro-environment around cancer cells is highly involved in cancer progression. It was reported that luteolin $(1-10 \mu \mathrm{M})$ effectively suppressed IL-4 induced polarization of tumor-associated macrophages (major components of cancer cell micro-environment) and consequently inhibited monocyte recruitment and migration of Lewis lung cancer cells [86]. Hypoxia is another important component of cancer micro-environment. In non-small lung cancer cells, high levels of hypoxia are usually related to EMT. Luteolin treatment $(5-50 \mu \mathrm{M})$ to non-small lung cancer cells could inhibit hypoxia-induced EMT as well as cell viability, proliferation and motility. The effect was at least partly through suppressing the expression of integrin $\beta 1$ and FAK [87]. More importantly, luteolin administration (i.p. 10 and $30 \mathrm{mg} / \mathrm{kg}$ /day) effectively suppressed tumor growth in a lung cancer mice model with EGF receptor mutation and drug resistance [88].

In a human gastric cancer xenograft model, luteolin treatment (i.p. $10 \mathrm{mg} / \mathrm{kg} /$ day) significantly suppressed tumor growth, without causing apparent toxicity or weight loss [89]. Luteolin treatment $(20-100 \mu \mathrm{M})$ also exhibited cytotoxic effect on several colon cancer cell lines through induction of apoptosis and cell cycle arrest. Meantime, the same treatment exerted no evident toxicity on normal differentiated enterocytes [90,91]. These effects of luteolin might be associated with down-regulation of the IGF-1-mediated PI3K/Akt and ERK1/2 pathways, and suppression of synthesis of sphingosine-1-phosphate and ceramide traffic [90,91]. Besides, it was indicated that ER $\alpha$ was a possible target of luteolin. By down-regulating the expression of ER $\alpha$, luteolin treatment $(10-40 \mu \mathrm{M})$ suppressed IGF-1-mediated PI3K/Akt pathway, leading to growth inhibition of MCF-7 breast cancer cells accompanied by cell cycle arrest and apoptosis [92]. In the MDA-MB-231 ER-negative breast cancer cells, luteolin treatment also induced cell cycle arrest and apoptosis possibly mediated by EGFR. In addition, luteolin-supplemented diet $(0.01 \%$ or $0.05 \%)$ effectively reduced tumor burden in mice inoculated with MDA-MB-231 cells [93]. Besides, in LNCaP prostate cancer cells, luteolin treatment $(30 \mu \mathrm{M})$ arrested the cell cycle at $\mathrm{G}_{1} / \mathrm{S}$ phase, induced cell apoptosis and inhibited cell invasion. The possible mechanism might be down-regulated expression of prostate-specific antigen by luteolin [94]. 


\subsection{Flavonols}

Flavonols (Figure 6) are probably the most widely distributed flavonoids in foods, but they are usually present at relatively low concentrations [2]. Representatives of this subclass are quercetin, kaempferol, myricetin, galangin and isorhamnetin.

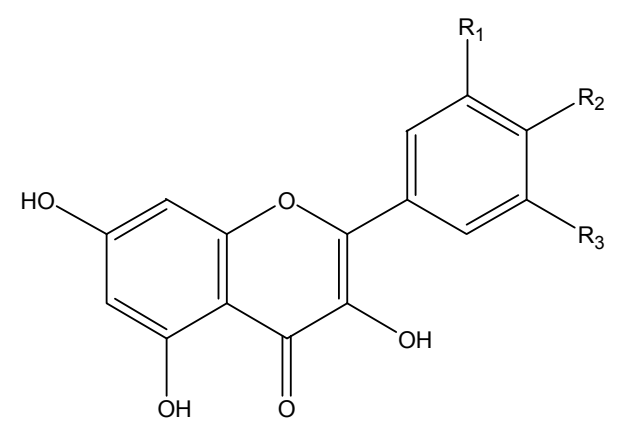

Figure 6. The chemical structures of quercetin $\left(R_{1}=H, R_{2}=R_{3}=O H\right)$, kaempferol $\left(R_{1}=R_{3}=H\right.$, $\left.\mathrm{R}_{2}=\mathrm{OH}\right)$, myricetin $\left(\mathrm{R}_{1}=\mathrm{R}_{2}=\mathrm{R}_{3}=\mathrm{OH}\right)$, galangin $\left(\mathrm{R}_{1}=\mathrm{R}_{2}=\mathrm{R}_{3}=H\right)$ and isorhamnetin $\left(\mathrm{R}_{1}=\mathrm{H}\right.$, $\mathrm{R}_{2}=\mathrm{OH}, \mathrm{R}_{3}=\mathrm{OCH} 3$ ).

\subsubsection{Quercetin}

Quercetin treatment $\left(\mathrm{IC}_{50} 2.30 \pm 0.26 \mu \mathrm{M}\right)$ to $\mathrm{A} 549$ lung cancer cells induced growth inhibition via apoptosis. In similar ways, quercetin $(8.4 \mathrm{mg} / \mathrm{kg})$ inhibited the growth of transplanted lung cancer in nude mice [95]. On the other hand, though exposure of gastric cancer cells to quercetin ( $\mathrm{IC}_{50} 40$ and $160 \mu \mathrm{M}$ in two cell lines respectively) led to pronounced apoptosis, the treatment also induced protective autophagy, which impaired the anticancer effects of quercetin [96]. AMPK-mediated signaling pathway, which participates in regulation of energy homeostasis, is important for the adaptive responses of cancer cells and might be critical for the effects of quercetin. A study found that quercetin treatment (i.p. $50 \mathrm{mg} / \mathrm{kg} /$ day) significantly decreased tumor volume in the HCT116 colon cancer xenograft model by reducing AMPK activity. Similarly, by inhibiting AMPK, the apoptosis induced by quercetin $(100 \mu \mathrm{M})$ was more pronounced under hypoxic conditions than normoxic conditions in HCT116 colon cancer cells [97]. Besides, in a mouse model of colorectal cancer, dietary quercetin supplementation $(25 \mathrm{mg} / \mathrm{kg} /$ day) alleviated several symptoms of cachexia such as body weight, grip strength and muscle mass [98]. Another study found that quercetin treatment $(0.05-0.15 \mathrm{mM})$ to HCC cells effectively inhibited proliferation and induced apoptosis through up-regulation of Bad and Bax, and concomitant down-regulating Bcl-2 and survivin. Importantly, quercetin (i.p. $40 \mathrm{mg} / \mathrm{kg} /$ day) also exhibited excellent inhibition effects on tumor growth in mice [99].

The exposure of MCF-7 breast cancer cells to quercetin (50-200 $\mu \mathrm{M})$ caused a dose- and time-dependent decrease of proliferation through induction of apoptosis, which was accompanied by up-regulation of Bax and down-regulation of Bcl-2 [100]. The inhibition of insulin receptor signaling by quercetin $(100 \mu \mathrm{M})$ also impairs proliferation of MDA-MB-231 breast cancer cells. Quercetin feeding ( $50 \mu \mathrm{g} /$ mouse/day) resulted in a significant decrease of tumor growth in mice model of breast cancer [101]. In another study, quercetin $(1-100 \mu \mathrm{M})$ inhibited breast cancer cells growth and migration via reversing EMT, which was linked with the modulation of $\beta$-catenin as well as its target genes (e.g., cyclin D1 and c-Myc) [102]. VEGFR2-mediated pathway participates in the angiogenesis in cancer development. Quercetin (34 mg/ $\mathrm{kg} /$ day) inhibited angiogenesis of breast cancer xenograft in mice, which was performed through suppressing this pathway [103]. Besides, dietary quercetin ( $200 \mathrm{mg} / \mathrm{kg}$ body weight thrice a week) protected against prostate carcinogenesis induced by hormone (testosterone) and carcinogen ( $N$-methyl- $N$-nitrosourea) in rats [104]. In another preclinical rat model of prostate cancer, oral administration of quercetin $(200 \mathrm{mg} / \mathrm{kg} /$ day $)$ prevented cancer development by down-regulating the cell survival, proliferative and anti-apoptotic proteins [105]. In HeLa cervical 
cancer cells, quercetin treatment $(110.38 \pm 0.66 \mu \mathrm{M})$ led to ROS accumulation to induce apoptosis and $\mathrm{G}_{2} / \mathrm{M}$ cell cycle arrest [106].

\subsubsection{Kaempferol}

Kaempferol is a natural flavonol broadly distributed in apples, strawberries, broccoli and beans, and exhibits a wide range of beneficial properties, such as cardioprotective, anti-diabetic, and anti-allergic effects [107]. In A549 lung cancer cells, kaempferol treatment inhibited TGF- $\beta 1$-induced EMT and migration through suppressing the phosphorylation of smad3 mediated by Akt1 [107]. Another study reported that kaempferol treatment exhibited significant anti-proliferative effects on MKN28 and SGC7901 gastric cancer cells without apparent cytotoxicity to normal gastric epithelial cells. The possible mechanism might be induction of apoptosis and $\mathrm{G}_{2} / \mathrm{M}$ cell cycle arrest. More importantly, administration of kaempferol suppressed gastric cancer growth in vivo [108]. In HT-29 colon cancer cells, the treatment of kaempferol $(0-60 \mu \mathrm{M})$ provoked apoptosis by activating the death receptor pathway and mitochondrial pathway [109]. Another study in SK-HEP-1 human liver cancer cells found $\mathrm{G}_{2} / \mathrm{M}$ cell cycle arrest and autophagy following kaempferol treatment, which might be the result of the modulation of CDK1/cyclin B expression and AMPK and AKT signaling pathways [110]. Kaempferol induced apoptosis in MCF-7 breast cancer cells [111]. In the same cell line, treatment of kaempferol $(100 \mu \mathrm{M})$ also significantly suppressed glucose uptake mediated by GLUT1, which might be another mechanism underlying its anti-proliferative effects [112]. Besides, both in vitro and in vivo study revealed that kaempferol could prevent breast cancer induced by $17 \beta$-estradiol or triclosn, an exogenous estrogen [113]. Kaempferol treatment also inhibited breast cell invasion through down-regulating the expression and activity of MMP-9 by blocking the PKC $/ \mathrm{MAPK} / \mathrm{AP}-1$ cascades [114].

\subsubsection{Myricetin}

Myricetin is rich in berries, walnuts and herbs. Myricetin treatment to gastric cancer cells exhibited anti-proliferative effects by inducing apoptosis and cell cycle arrest [115]. In HCT-15 human colon cancer cells, myricetin treatment induced apoptotic cell death by modulating the Bax/Bcl-2-dependent pathway [116]. Similarly, myricetin also decreased the expression of anti-apoptotic survivin and Bcl-2 and increased the expression of pro-apoptotic Bax in HCC cells and in vivo [117].

\subsubsection{Galangin}

Galangin is a naturally occurring flavonoid rich in oregano as well as in Alpinis officinarum, a common spice in Asia. Galangin treatment (50-200 $\mu \mathrm{M})$ to SNU-484 human gastric cancer cells dose- and time-dependently inhibited cell proliferation through induction of apoptosis [118]. Besides, in hepG2 liver cancer cells, galangin treatment $(10-30 \mu \mathrm{M})$ significantly inhibited chemical-induced cell invasion and metastasis by modulating the PKC/ERK pathway [119]. Another study suggested that galangin $(79.8-134 \mu \mathrm{M})$ could promote ER stress to suppress the proliferation of HCC cells [120].

\subsubsection{Isorhamnetin}

Isorhamnetin is a natural flavonoid rich in fruits and vegetables as well as tea, and is also an immediate metabolite of quercetin, which has drawn attention for its excellent anti-inflammatory and anticancer activities [121,122].

Treatment of isorhamnetin to A549 lung cancer cells induced apoptotic cell death, which was accompanied by the up-regulation of capase-3, Bax, p53 and the down-regulation of Bcl-2, cyclin D1 and PCNA protein. More importantly, isorhamnetin administration to tumor-bearing mice significantly suppressed tumor growth [123]. Additionally, isorhamnetin suppressed gastric cancer proliferation and invasion, and induced apoptosis by modulating the peroxisome proliferator-activated receptor $\gamma$ (PPAR $\gamma$ )-mediated pathway in vitro and in vivo [124]. Another study investigated the anti-proliferative activity of isorhamnetin in several human colorectal cancer cell lines (HT29, HCT116 
and SW480), and found that the compound inhibited proliferation of all tested cancer cells by blocking the PI3K/Akt/mTOR pathway [125]. Both in vitro and in vivo experiments suggested that the anticancer property of isorhamnetin in colon cancer involved inhibition of inflammation as well as oncogenic Src activity and consequential loss of nuclear $\beta$-catenin [126]. Another study documented the anti-proliferative and pro-apoptotic activities of isorhamnetin in breast cancer cells, which was probably mediated by the Akt and MAPK kinase signaling pathways [121]. Besides, in MDA-MB-231 breast cancer cells, isorhamnetin treatment significantly suppressed cell invasion by down-regulating MMP-2 and MMP-9, which might be associated with the inhibition of p38 MAPK and STAT3 [122].

\subsection{Isoflavones}

Due to structural similarities to estrogen, isoflavones (Figure 7) have been classified as phytoestrogen, another important class of phytochemicals. Genistein and daidzein from soy are representative members of this subclass [2].

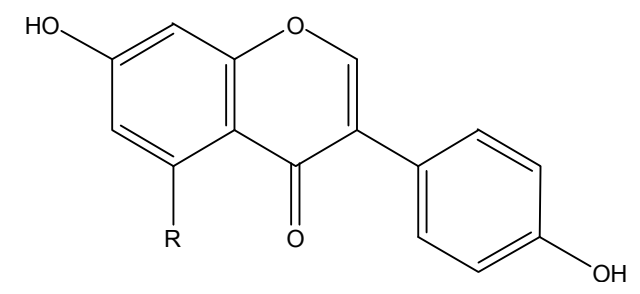

Figure 7. The chemical structures of daidzein $(\mathrm{R}=\mathrm{H})$ and genistein $(\mathrm{R}=\mathrm{OH})$.

\subsubsection{Daidzein}

Data indicated that daidzein was an apoptosis inducer in liver cancer cells and treatment of daidzein (200-600 $\mu \mathrm{M})$ caused mitochondrial-dependent apoptosis mediated by the Bcl-2 family [127]. In an in vitro study, daidzein $(50 \mu \mathrm{M})$ as well as its metabolites R-equol and S-equol, suppressed the invasion of MDA-MB-231 human breast cancer cells at least partly through the down-regulation of MMP-2 expression [128]. However, another study reported that daidzein treatment $(3-10 \mu \mathrm{M})$ up-regulated proto-oncogene BRF2 in ER-positive breast cancer cells but not ER-negative cells. Female mice treated with a high-isoflavone commercial diet showed significantly increased BRF2 expression [129].

\subsubsection{Genistein}

Genistein is the most abundant isoflavonoid contained in soy as well as soy products and is also a major active component of hormonal supplements for menopausal women [10]. In H446 lung cancer cells, genistein treatment $(25-75 \mu \mathrm{M})$ effectively suppressed the cell proliferation and migration, which was accompanied by induction of apoptosis and $\mathrm{G}_{2} / \mathrm{M}$ cell cycle arrest. Importantly, the treatment also suppressed the expression of Forehead box protein M1 and its target genes regulating cell cycle or apoptosis, such as survivin, cyclin B1 and Cdc25. Therefore, the effects of genistein were at least partly mediated by Forkhead box protein M1 [130]. In addition, genistein treatment (15 $\mu \mathrm{M})$ to gastric cancer cells suppressed the cancer cell stem-like abilities, includingself-renewal, drug resistance and carcinogenicity, which might be due to down-regulation of stemness related genes as well as drug resistance gene ABCG2. Meantime, genistein (i.p. $1.5 \mathrm{mg} / \mathrm{kg} /$ day) significantly decreased the weight and size of gastric cancer inoculated in nude mice [131]. Besides, genistein $(25-100 \mu \mathrm{M})$ exhibited anti-proliferative and pro-apoptotic effects on colon cancer cells. The study indicated that inhibition of oncogenic miR-95, Akt and SGK as well as phosphorylation of Akt could be involved in these anticancer effects. Moreover, genistein treatment (i.p. 20,50, $80 \mathrm{mg} / \mathrm{kg} /$ day) to mice significantly decreased the weight and size of transplanted colorectal cancer [132]. Oral administration of genistein also inhibited angiogenesis and suppressed metastasis of colorectal cancer to distant organs in mice [133]. 
According to in vitro studies, the anticancer effects of genistein on colorectal cancer might involve the suppression of Wnt, NF-kB signaling pathways [134,135]. Additionally, in nude mice inoculated with liver cancer cells, oral administration of genistein $(50 \mathrm{mg} / \mathrm{kg} /$ day) significantly suppressed the intrahepatic metastasis [136].

Genistein treatment $(5,10$ or $20 \mu \mathrm{M})$ elicited growth inhibition of MDA-MB-231 breast cancer cells, which was accompanied by apoptosis and $\mathrm{G}_{2} / \mathrm{M}$ cell cycle arrest. This effect might be mediated by down-regulation of the NF-KB activity via the Notch-1 pathway [137]. In MCf-7 breast cancer cells, genistein treatment $(15$ and $30 \mu \mathrm{M})$ also inhibited cell growth, induced apoptosis and decreased the CD $44^{+} \mathrm{CD} 24^{-}$cancer stem cells. Importantly, genistein (i.p. 20 and $50 \mathrm{mg} / \mathrm{kg} /$ day) could also target breast cancer stem cells to reduce the volume and weight of xenograft tumors in nude mice. The effects might be correlated with down-regulation of Hedgehog-Gli1 signaling pathway [138]. However, some studies found that genistein has adverse effects on breast cancer treatment. A study suggested that the $\mathrm{ER} \alpha / \mathrm{ER} \beta$ ratio could be a determinant of genistein functions in breast cancer. In breast cancer with a low ER $\alpha / E R \beta$ ratio (e.g., T4D7 cells), genistein treatment might be harmless or even beneficial, while in breast cancer with a high ratio (e.g., MCF-7 cells), the treatment might be counterproductive [139]. Genistein $(10 \mu \mathrm{M})$ could also affect the expression and function of ATP-binding cassette drug transporters in breast cancer cells. The effect resulted in an increase of efflux and resistance of chemotherapeutic drugs (doxorubicin and mitoxantrone) in MCF-7 cells [10]. Moreover, in athymic mice model of breast cancer, a low dose long-term treatment of genistein $(\leq 500 \mathrm{ppm})$ led to tumor growth as well as more aggressive and advanced phenotypes [140]. Genistein was also reported to have different effects on prostate cancer cells. In LAPC-4 cells with wild androgen receptor, genistein treatment $(0.5-50 \mu \mathrm{M})$ dose dependently suppressed cell proliferation and androgen receptor. However, in LNCaP cells with T877A mutant androgen receptor, genistein promoted cancer cell growth and androgen receptor at physiological concentration $(0.5-5 \mu \mathrm{M})$, but showed inhibitory activities at higher concentration. Similar biphasic activities of genistein were also observed in PC-3 cells transfected with androgen receptor mutants [141]. In addition, the exposure of HeLa cervical cancer cells to genistein $\left(\mathrm{IC}_{50} 100 \mu \mathrm{M}\right)$ led to growth inhibition mediated by apoptosis and $\mathrm{G}_{2} / \mathrm{M}$ cell cycle arrest and suppressed cell migration by modulating MMP-9 and TIMP-1 [142].

\subsection{Phenolic Acids}

Phenolic acids (Figure 8) can be mainly classified into two groups, hydroxybenzoic acid and hydroxycinnamic acid. Hydroxybenzoic acids present in few edible plants and are not considered to be of high nutritional interest. The other group is more common in food, but its consumption is highly variable, depending on intake of coffee [2].

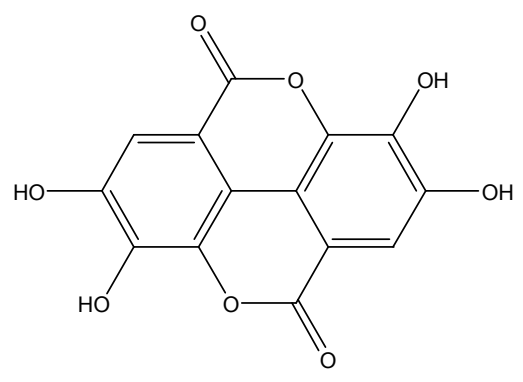

(a)

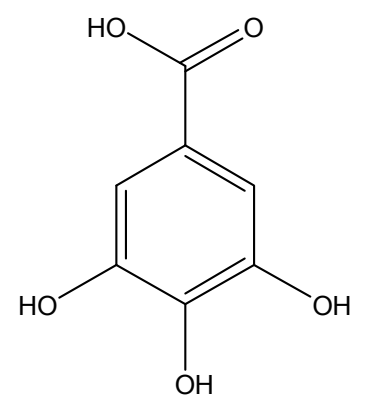

(b)

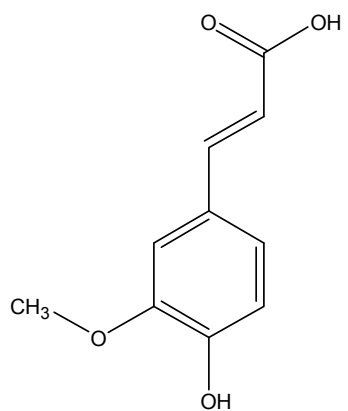

(c)

Figure 8. The chemical structures of (a) ellagic acid; (b) gallic acid and (c) ferulic acid.

\subsubsection{Ellagic Acid}

Ellagic acid is a dietary flavonoid abundantly in pomegranate, grapes, strawberries and walnuts [143]. Ellagic acid (50-200 $\mu \mathrm{M})$ exerted anti-proliferative and pro-apoptotic effects in colon 
cancer cell lines in a concentration dependent manner [144]. Besides, in a chemical-induced liver cancer rat model, oral administration of ellagic acid (30 mg/kg/day) normalized the permeability of mitochondrial outer membrane and alleviated inflammation-mediated cancer cell proliferation [145]. Ellagic acid (10-40 $\mu \mathrm{g} / \mathrm{mL}$ ) also showed growth inhibitory effects on MCF-7 breast cancer cells, which was accompanied by $\mathrm{G}_{0} / \mathrm{G}_{1}$ cell cycle arrest. The modulation of the TGF- $\beta /$ Smads signaling pathway was suggested to be the potential mechanism [143]. Furthermore, exposure to ellagic acid (i.p. 50 and $100 \mathrm{mg} / \mathrm{kg} /$ day) suppressed tumor growth and angiogenesis in mice implanted with breast cancer cells [146]. In another study, non-cytotoxic dose of ellagic acid (25 and $50 \mu \mathrm{M})$ to androgen independent prostate cancer cells markedly suppressed the cell invasion and motility. The effect might be the result of down-regulation of MMPs [147]. Besides, at higher dose (10-100 $\mu \mathrm{M})$, ellagic acid treatment was found to induce growth inhibition and caspase-dependent apoptosis in PC3 prostate cancer cells in a dose responsive manner [148].

\subsubsection{Gallic Acid}

Gallic acid is widely distributed in plant-based food in free forms as well as part of hydrolyzable tannins. Blackberry, raspberry, walnuts, chocolate, wine, green tea and vinegar are rich sources of the compound. Gallic acid possesses various pharmacological activities, such as anti-microbial, anti-inflammatory and anticancer activities $[149,150]$. Exposure to gallic acid $(3.5 \mu \mathrm{M})$ inhibited migration of AGS gastric cancer cells, which was possibly mediated by up-regulation of RhoB as well as down-regulation of AKT/small GTPase signals and NF- $\mathrm{BB}$ activity. In addition to this, compared with the control, feeding with gallic acid solution $(0.25 \%$ and $0.5 \%)$ significantly decreased tumor size and weight in mice models of gastric cancer [151]. The ROS-dependent pro-apoptotic effects of gallic acid led to decreased viability of different cancer cells, such as HCT-15 colon cancer cells (200 $\mu \mathrm{M})$ and LNCaP prostate cancer cells $(80 \mu \mathrm{g} / \mathrm{mL})[149,152]$. Besides, gallic acid treatment selectively inhibited growth of liver cancer cells through the mitochondria-mediated apoptotic pathways ( $\mathrm{IC}_{50}$ for cancer cells $28.5 \pm 1.6 \mu \mathrm{g} / \mathrm{mL}$ and $22.1 \pm 1.4 \mu \mathrm{g} / \mathrm{mL}$, for normal human hepatocytes $80.9 \pm 4.6 \mu \mathrm{g} / \mathrm{mL}$ ) [153] Studies on MCF-7 breast cancer cells also showed that gallic acid treatment inhibited cell proliferation ( $\mathrm{IC}_{50} 80.5 \mu \mathrm{M}$ ) and induced apoptosis via both the extrinsic and intrinsic pathways [150]. Additionally, exposure to gallic acid ( 25 and $50 \mu \mathrm{M})$ suppressed the invasion and migration of PC-3 prostate cancer cells through down-regulation of MMP-2 and MMP-9 [154]. In another study, gallic acid (50, 100, and $200 \mu \mathrm{M}$ ) in PC-3 prostate cancer cells provoked DNA damage and inhibited expression of DNA repair genes, which contributed to gallic-induced growth inhibition [155]. Treatment with gallic acid (10-40 $\mu \mathrm{g} / \mathrm{mL})$ decreased cell viability, proliferation, invasion and angiogenesis HeLa and HTB-35 cervical cancer cells, but showed less cytotoxicity on normal cells (HUVEC), indicating a potential role of the compound in cervical cancer treatment [156].

\subsubsection{Ferulic Acid}

The main dietary sources of ferulic acid are cereal grains, particularly the outer parts of grain. The compound has attracted great attention due to its therapeutic activities against various diseases, such as cancer, cardiovascular and neurodegenerative diseases [157,158].

It was reported that ferulic acid was a pro-oxidant at high concentration or in the presence of metal ions such as copper. Since the increased level of copper was observed in many cancers, and cancer cells are usually under greater oxidative stress than normal cells, the pro-oxidant ability of ferulic acid might lead to selective cytotoxicity to cancer cells [157]. Ferulic acid $(10 \mu \mathrm{g} / \mathrm{mL})$ also decreased cell viability and enhanced efficacy of radiotherapy in two cervical cancer cell lines (HeLa and ME-180), possibly through promotion of ROS [159]. Another study on prostate cancer found that the effects of ferulic acid varied with cell types. Ferulic acid treatment caused cell cycle arrest in PC-3 cells (IC $50300 \mu \mathrm{M}$ ), and led to apoptosis in LNCaP cells (IC50 $500 \mu \mathrm{M})$ [158]. 


\subsection{Lignans}

Lignans (Figure 9) are widely present in plants, such as flaxseed, sesame, and seeds of Arctium lappa. Secoisolariciresinol diglucoside (SDG) is a natural lignan rich in flaxseed, and can be converted into more biologically active lignans (enterodiol and enterolactone) by human colon bacteria. These lignans are structurally similar to estradiol; thus, they may have anticancer effects for hormone-related cancers, such as breast, prostate and colon cancer. For example, SDG was reported to possess selective estrogen receptor modulating effects and display anti-estrogenic activity in a high estrogen environment. Treatment with SDG (100 ppm in diet) normalized some biomarkers changed by carcinogen in mammary gland tissue of mice [160]. In another study, enterolactone modulated expression of genes involved in cell proliferation and cell cycle of MDA-MB-231 breast cancer cells $\left(\mathrm{IC}_{50} 261.9 \pm 10.5 \mu \mathrm{M}\right)[161]$.<smiles>COc1cc(CC(CO)C(CO)Cc2ccc(O)c(OC)c2)ccc1O</smiles>

(a)

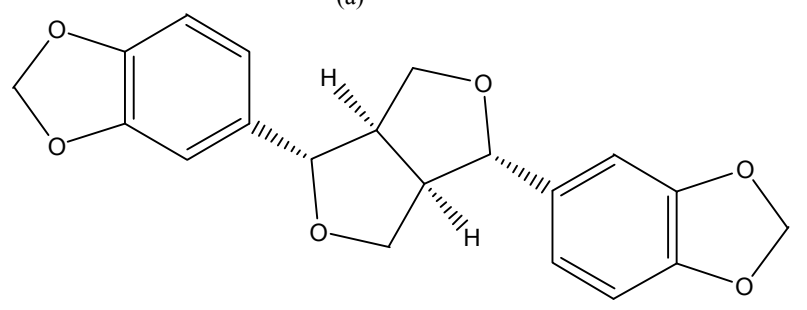

(b)

Figure 9. The chemical structures of (a) Secoisolariciresinol diglucoside and (b) sesamin.

Sesamin is a major lipid soluble lignan from sesame oil. Sesamin treatment $(1,10$ and $50 \mu \mathrm{M})$ dose-dependently decreased cell viability and increased apoptosis in MCF-7 breast cancer cells. The lignan (10-100 $\mu \mathrm{M})$ also inhibited the pro-angiogenic activity of macrophages in MCF-7 cells by down-regulating VEGF and MMP-9 [162]. Besides, it was suggested that STAT3 played an important role in sesamin $(25-125 \mu \mathrm{M})$ induced $\mathrm{G}_{2} / \mathrm{M}$ cell cycle arrest and apoptosis in HepG2 cells [163]. Sesamin $(10-100 \mu \mathrm{g} / \mathrm{mL})$ could suppress lipopolysaccharide-induced proliferation and invasion of PC3 prostate cancer cells by modulating the p38-MAPK and NF- $\mathrm{kB}$ signaling pathways. Likewise, sesamin pretreatment $(10 \mathrm{mg} / \mathrm{kg}$ every three days, injection) suppressed PC 3 cells-derived tumor growth triggered by lipopolysaccharide in mice [164].

\subsection{Stilbenes}

Natural stilbenes (Figure 10) are another important group of polyphenols. Though they only exist in a limited group of plant families, the prominent health benefits of resveratrol, an important member of this class, have attracted a lot of studies into natural stilbenes. 


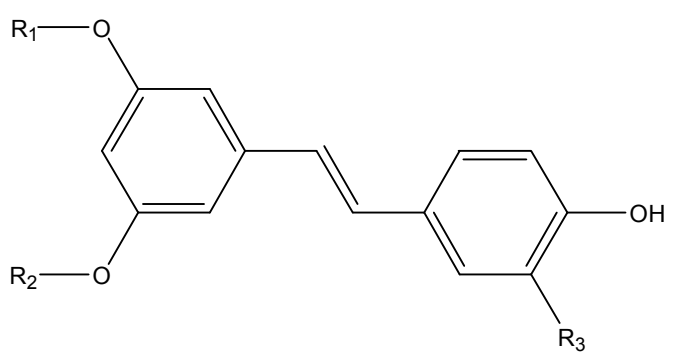

Figure 10. The chemical structures of resveratrol $\left(R_{1}=R_{2}=R_{3}=H\right)$, pterostilbene $\left(R_{1}=R_{2}=C H 3\right.$, $\left.\mathrm{R}_{3}=\mathrm{OH}\right)$, piceatannol $\left(\mathrm{R}_{1}=\mathrm{R}_{2}=\mathrm{H}, \mathrm{R}_{3}=\mathrm{OH}\right)$.

\subsubsection{Resveratrol}

Resveratrol is predominantly found in red wine, grapes and berries. X-ray repair cross complement group 1 (XRCC1) participates in base excision repair. It was reported that resveratrol treatment $(5-50 \mu \mathrm{M})$ could suppress XRCC1 expression, thus leading to enhanced chemosensitivity to etoposide (a topoisomerase II inhibitor) of human non-small-cell lung cancer cell lines [165]. Besides, it was reported that $20 \mu \mathrm{M}$ resveratrol treatment significantly suppressed invasion and metastasis of A549 lung cancer cells by inhibiting EMT [11].

In gastric cancer cells, resveratrol treatment ( 25 and $50 \mu \mathrm{M}$ ) arrested cancer cells in the $\mathrm{G}_{1}$ phase, resulting in senescence instead of apoptosis. In similar ways, resveratrol (40 mg/ $\mathrm{kg} /$ day) inhibited gastric cancer development in nude mice [166]. However, at higher concentrations (50-200 $\mu \mathrm{M})$, resveratrol induced DNA damage and apoptosis in human gastric adenocarcinoma cells via promoting generation of ROS [167]. Resveratrol induced apoptosis in different colon cancer cell lines via modulating diverse targets. For example, resveratrol induced caspase- 8 and -3 dependent apoptosis via ROS-triggered autophagy in HT-29 (IC $50150 \mu \mathrm{M})$ and COLO $201\left(\mathrm{IC}_{50} 75 \mu \mathrm{M}\right)$ human colon cancer cells [168]. A study reported that the indirect DNA-damaging effects of resveratrol $(30 \mu \mathrm{M})$ in colon cancer cells were mainly caused by overproduction of ROS [169]. Another study suggested that the DNA damage induced by resveratrol $(25 \mu \mathrm{M})$ was due to topoisomerase II poisoning rather than promoting ROS production [170]. Besides, resveratrol $(50 \mu \mathrm{M})$ suppressed expression of multi-drug resistance protein 1 (MDR1) and drug efflux in drug-resistant colorectal cancer cells [171]. Activating mutations in Kras contribute to sporadic colorectal cancer. An in vivo study found that dietary supplements of resveratrol (equivalent to 105 and $210 \mathrm{mg}$ daily for humans) protected against formation and growth of colorectal cancer by suppressing expression of Kras [172]. In addition, in colorectal cancer patients, following oral administration of resveratrol, high concentrations of resveratrol conjugates (mainly RSV-3-O-sulfate, RSV-3-O-glucuronide and RSV-4'-O-glucuronide) were found in the colorectum. Mixture of these conjugates exhibited synergistic anticancer effects by inducing DNA damage and apoptosis in human colorectal cancer cells. Therefore, despite the low bioavailability of resveratrol, the anti-carcinogenic properties could also be achieved by its main metabolites [173]. Cancer stem cells possess the ability to self-renew and are important for tumor generation. Three signaling pathways regulated the self-renewal of breast cancer stem cells are Wnt, Notch and Hedgehog. It was reported that resveratrol could inhibit the Wnt/ $\beta$-catenin signaling pathway in breast cancer stem cells. Accordingly, resveratrol treatment (i.v. $100 \mathrm{mg} / \mathrm{kg} /$ day) to mice significantly suppressed tumor growth as well as the breast cancer stem cells in primary xenografts [174]. Resveratrol is also a powerful chemopreventive agent against liver cancer. At low concentration, resveratrol treatment $(25-100 \mu \mathrm{M})$ inhibited metastasis of HCC cells and decreased expression of urokinase-type plasminogen activator ( $\mathrm{u}-\mathrm{PA})$, which involved down-regulation of the SP-1 signaling pathway [175]. Besides, in N-nitrosodiethylamine treated rat, the oral administration of resveratrol $(20 \mathrm{mg} / \mathrm{kg} /$ day) either at early or advanced stages of liver carcinogenesis was equally effective, possibly mediated by apoptosis [176]. In androgen independent prostate cancer cells, resveratrol treatment $(25-100 \mu \mathrm{M})$ induced autophagy-mediated cell death [177]. In addition, 
oral administration of resveratrol (30 mg/ $\mathrm{kg}$ thrice a week) to mice inhibited proliferation, induced apoptosis, and suppressed angiogenesis and metastasis of prostate cancer [178]. In several cervical cancer cells, resveratrol treatment (150-250 $\mu \mathrm{M})$ caused cell cycle arrest and apoptosis [179].

\subsubsection{Pterostilbene}

Pterostilbene is a natural dimethoxylated analog of resveratrol mainly found in blueberries. The hydroxyl group substitution with methoxyl groups gives pterostilbene greater lipophilicity, oral bioavailability and biological half-life than resveratrol.

Pinostilbene is a major metabolite of pterostilbene in the colon of mice. At physiologically relevant concentrations (20 and $40 \mu \mathrm{M}$ ), it significantly inhibited cell growth, and induced apoptosis and S phase arrest of human colon cancer cells. Therefore, pinostilbene might be important for the anticancer effects of orally administered pterostilbene [180]. In addition, pterostilbene treatment $(25-75 \mu \mathrm{M})$ was able to induce apoptosis in breast cancer cells via Bax activation and over-expression [181]. MicroRNAs (miRNAs) are small non-coding RNAs, which control post-transcriptional expression of genes. It was suggested that miRNAs are highly involved in the development of cancer [48]. A study reported that pterostilbene treatment inhibited EMT and metastasis of breast cancer cells $(2.5-10 \mu \mathrm{M})$. Mechanistic investigations also showed an up-regulation of miR-205 following pterostilbene treatment, which inhibited the Src/Fak signaling and suppressed tumor growth and metastasis in MDA-MB-231-bearing NOD/SCID mice (i.p. $10 \mathrm{mg} / \mathrm{kg}$ thrice a week) [182]. Another study found that pterostilbene treatment selectively killed breast cancer stem cells $\left(\mathrm{IC}_{50} 25 \mu \mathrm{M}\right)$ and sensitized these cells to chemotherapeutic drug paclitaxel [183]. Besides, pterostilbene treatment $(80 \mu \mathrm{M})$ activated AMPK in both p53 positive and negative human prostate cancer cells, but the cell fate following AMPK activation was affected by p53 status. In p53 positive LNCaP cells, pterostilbene caused $\mathrm{G}_{1}$ cell cycle arrest by increasing p53 expression, while in p53 negative PC3 cells, pterostilbene treatment induced apoptosis [184]. In another study, pterostilbene (i.p. $50 \mathrm{mg} / \mathrm{kg} /$ day) inhibited tumor growth in mice models of prostate cancer [185].

\subsubsection{Piceatannol}

Piceatannol is a hydroxylated analog of resveratrol present in a variety of foods, for example, grapes, berries, passion fruit, and white tea. In colorectal cancer cells, piceatannol treatment $(30 \mu \mathrm{M})$ induced apoptosis by up-regulating miR-129, and thus down-regulating Bcl-2, which is a known target of miR-129 [186]. Besides, in prostate cancer cells, treatment with piceatannol (25 and $50 \mu \mathrm{M})$ inhibited proliferation, and induced cell cycle arrest and apoptosis, which might be associated with down-regulated mTOR [187]. Piceatannol was also a potential anti-invasive and anti-metastasis agent on prostate cancer cells. The oral administration of piceatannol ( $20 \mathrm{mg} / \mathrm{kg} / \mathrm{day})$ significantly suppressed the metastasis of prostate cancer to lung in mice [188].

The anticancer activities and potential mechanisms of the polyphenols reviewed in this section were summarized in Table 3 and Figure 11. Due to the critical role of cancer stem cells in cancer development and treatment, the anti-cancer stem cell effects of polyphenols were summarized in Table 4. It should be noted that curcumin is not discussed in this section because it has been extensively reviewed [189-191]. Besides, the bioavailability of many polyphenols is low, which might hamper their application in cancer treatment (Table 5) [6]. 
Table 3. The in vitro and in vivo anticancer activities of natural polyphenols.

\begin{tabular}{|c|c|c|c|c|}
\hline Polyphenol & Study Type & Dose & Main Effects & References \\
\hline \multicolumn{5}{|l|}{ Lung Cancer } \\
\hline peonidin-3-glucoside & in vitro & $10-40 \mu \mathrm{M}$ & $\begin{array}{l}\text { inhibiting cancer cell invasion, motility, } \\
\text { secretion of MMPs and u-PA }\end{array}$ & [33] \\
\hline anthocyanidins & in vivo & $0.5 \mathrm{mg} / \mathrm{mouse}$ & inhibiting tumor growth & [7] \\
\hline xanthohumol & in vitro & $14-42 \mu \mathrm{M}$ & inducing apoptosis and cell cycle arrest & [38] \\
\hline EGCG & in vitro & $5-20 \mu \mathrm{M}$ & $\begin{array}{l}\text { suppressing cancer cell invasion, } \\
\text { migration, MMP-2 }\end{array}$ & [44] \\
\hline EGCG & in vivo & $\mathrm{NA}^{1}$ & suppressing nicotine-induced angiogenesis & [9] \\
\hline procyanidin $\mathrm{C} 1$ & in vitro & $1.25-40 \mu \mathrm{g} / \mathrm{mL}$ & inhibiting TGF- $\beta$-induced EMT & [56] \\
\hline naringenin & in vitro & $100 \mu \mathrm{M}$ & enhancing TRAIL-mediated apoptosis & [60] \\
\hline apigenin & in vitro & $40-160 \mu \mathrm{M}$ & inducing apoptosis and DNA damage & [74] \\
\hline chrysin & in vitro & $10 \mu \mathrm{M}$ & inducing apoptosis, AMPK activation, ROS & [83] \\
\hline luteolin & in vitro & $5-50 \mu \mathrm{M}$ & $\begin{array}{l}\text { inducing apoptosis, cell cycle arrest, } \\
\text { inhibiting monocyte recruitment, } \\
\text { migration, EMT }\end{array}$ & [85-87] \\
\hline luteolin & in vivo & $10-30 \mathrm{mg} / \mathrm{kg}$ & suppressing tumor growth & [88] \\
\hline quercetin & in vivo & $8.4 \mathrm{mg} / \mathrm{kg}$ & suppressing tumor growth & [95] \\
\hline kaempferol & in vitro & $10-50 \mu \mathrm{M}$ & $\begin{array}{l}\text { inhibiting TGF- } \beta 1 \text {-induced EMT } \\
\text { and migration }\end{array}$ & [107] \\
\hline isorhamnetin & in vivo & NA & suppressing tumor growth & [123] \\
\hline genistein & in vitro & $25-75 \mu \mathrm{M}$ & $\begin{array}{l}\text { suppressing cancer cell proliferation and } \\
\text { migration, accompanied by apoptosis and } \\
\text { cell cycle arrest }\end{array}$ & [130] \\
\hline resveratrol & in vitro & $5-50 \mu \mathrm{M}$ & $\begin{array}{l}\text { decreasing XRCC } 1 \text { expression, enhancing } \\
\text { chemosensitivity, suppressing } \\
\text { invasion, metastasis }\end{array}$ & {$[13,165]$} \\
\hline \multicolumn{5}{|l|}{ Gastric Cancer } \\
\hline EGCG & in vitro & 20-100 $\mu \mathrm{M}$ & $\begin{array}{l}\text { inducing apoptosis, down-regulating } \\
\text { survivin, the } \beta \text {-catenin signaling pathway }\end{array}$ & {$[45,46]$} \\
\hline naringenin & in vitro & $20-80 \mu \mathrm{M}$ & $\begin{array}{l}\text { inducing apoptosis, inhibiting cancer cell } \\
\text { proliferation, invasion, migration and the } \\
\text { AKT pathway }\end{array}$ & [61] \\
\hline hesperetin & in vivo & $20-40 \mathrm{mg} / \mathrm{kg}$ & suppressing tumor growth & [67] \\
\hline apigenin & in vitro & $20 \mu \mathrm{g} / \mathrm{mL}$ & inducing apoptosis & [75] \\
\hline apigenin & in vivo & $30-60 \mathrm{mg} / \mathrm{kg}$ & $\begin{array}{l}\text { preventing Helicobacter pylori-induced } \\
\text { atrophic gastritis and carcinogenesis }\end{array}$ & [76] \\
\hline luteolin & in vivo & $10 \mathrm{mg} / \mathrm{kg}$ & suppressing tumor growth & [89] \\
\hline quercetin & in vitro & $40-160 \mu \mathrm{M}$ & $\begin{array}{l}\text { inducing apoptosis and } \\
\text { protective autophagy }\end{array}$ & [96] \\
\hline kaempferol & in vivo & $20 \mathrm{mg} / \mathrm{kg}$ & suppressing tumor growth & [108] \\
\hline myricetin & in vitro & $20-40 \mu \mathrm{M}$ & inducing apoptosis and cell cycle arrest & [115] \\
\hline galangin & in vitro & 50-200 $\mu \mathrm{M}$ & inducing apoptosis & [118] \\
\hline isorhamnetin & in vivo & $1 \mathrm{mg} / \mathrm{kg}$ & $\begin{array}{l}\text { increasing PPAR- } \gamma \text {, decreasing Bcl-2 and } \\
\text { CD31 }\end{array}$ & [124] \\
\hline gallic acid & in vivo & $\begin{array}{l}0.25 \% \text { and } 0.5 \% \\
\text { in water }\end{array}$ & decreasing tumor size and weight & [151] \\
\hline resveratrol & in vitro & 50-200 $\mu \mathrm{M}$ & $\begin{array}{l}\text { inducing apoptosis, DNA damage, } \\
\text { ROS production }\end{array}$ & [167] \\
\hline resveratrol & in vivo & $40 \mathrm{mg} / \mathrm{kg}$ & suppressing tumor growth & [166] \\
\hline
\end{tabular}


Table 3. Cont

\begin{tabular}{|c|c|c|c|c|}
\hline Polyphenol & Study Type & Dose & Main Effects & References \\
\hline \multicolumn{5}{|c|}{ Colorectal Cancer } \\
\hline delphinidin & in vitro & $30-240 \mu \mathrm{M}$ & $\begin{array}{l}\text { inducing apoptosis, cell cycle arrest, } \\
\text { oxidative stress }\end{array}$ & [30] \\
\hline cyanidin & in vitro & $100 \mu \mathrm{M}$ & inducing oxidative stress & [35] \\
\hline EGCG & in vitro & $1-50 \mu \mathrm{M}$ & $\begin{array}{l}\text { inducing epigenetic alteration, apoptosis, } \\
\text { MAPK and Akt pathways activation }\end{array}$ & {$[47,49]$} \\
\hline procyanidins & in vitro & 50 and $100 \mu \mathrm{M}$ & inducing apoptosis and cell cycle arrest & [57] \\
\hline naringenin & in vitro & 50-200 $\mu \mathrm{M}$ & inducing apoptosis & [62] \\
\hline hesperetin & in vivo & $20 \mathrm{mg} / \mathrm{kg}$ & $\begin{array}{l}\text { suppressing chemical-induced } \\
\text { carcinogenesis }\end{array}$ & [68] \\
\hline apigenin & in vivo & $50 \mathrm{mg} / \mathrm{kg}$ & inhibiting tumor growth and metastasis & [77] \\
\hline chrysin & in vitro & $50-100 \mu \mathrm{M}$ & $\begin{array}{l}\text { inducing TNF-mediated apoptotic } \\
\text { cell death }\end{array}$ & [84] \\
\hline luteolin & in vitro & $20-100 \mu \mathrm{M}$ & inducing apoptosis and cell cycle arrest & [90] \\
\hline quercetin & in vivo & $25-50 \mathrm{mg} / \mathrm{kg}$ & $\begin{array}{l}\text { suppressing tumor growth by reducing } \\
\text { AMPK activity and alleviating } \\
\text { cachexia symptoms }\end{array}$ & {$[97,98]$} \\
\hline kaempferol & in vitro & $0-60 \mu \mathrm{M}$ & inducing apoptosis & [109] \\
\hline myricetin & in vitro & NA & inducing apoptosis & [116] \\
\hline isorhamnetin & in vivo & $200 \mathrm{~g} / \mathrm{kg}$ in diet & $\begin{array}{l}\text { suppressing mortality, tumor number, } \\
\text { tumor burden and chemical-induced } \\
\text { inflammatory responses }\end{array}$ & [126] \\
\hline genistein & in vivo & $20-80 \mathrm{mg} / \mathrm{kg}$ & $\begin{array}{l}\text { decreasing the weight and size of } \\
\text { transplanted tumor, inhibiting angiogenesis } \\
\text { and metastasis }\end{array}$ & {$[132,133]$} \\
\hline ellagic acid & in vitro & 50-200 $\mu \mathrm{M}$ & inducing apoptosis & [144] \\
\hline gallic acid & in vitro & $200 \mu \mathrm{M}$ & inducing apoptosis & [149] \\
\hline resveratrol & in vitro & $25-150 \mu \mathrm{M}$ & $\begin{array}{l}\text { inducing apoptosis, DNA damage and } \\
\text { suppressing drug resistance }\end{array}$ & [168-171] \\
\hline resveratrol & in vivo & $\begin{array}{l}\text { equal to } 105 \text { and } \\
210 \mathrm{mg} \text { for human }\end{array}$ & $\begin{array}{l}\text { suppressing tumor development by } \\
\text { modulation of Kras }\end{array}$ & [172] \\
\hline piceatannol & in vitro & $30 \mu \mathrm{M}$ & inducing apoptosis mediated by miR- 129 & [186] \\
\hline \multicolumn{5}{|l|}{ Liver Cancer } \\
\hline xanthohumol & in vitro & $5-40 \mu \mathrm{M}$ & $\begin{array}{l}\text { inducing apoptosis, modulating the } \\
\text { NF- } \mathrm{B} \text { / p } 53 \text { and the Notch1 } \\
\text { signaling pathways }\end{array}$ & {$[39,40]$} \\
\hline naringenin & in vitro & $25-200 \mu \mathrm{M}$ & $\begin{array}{l}\text { suppressing TPA-induced cancer cell } \\
\text { invasion, inducing apoptosis and cell } \\
\text { cycle arrest }\end{array}$ & {$[63,64]$} \\
\hline quercetin & in vivo & $40 \mathrm{mg} / \mathrm{kg}$ & suppressing tumor growth & [99] \\
\hline kaempferol & in vitro & $25-100 \mu \mathrm{M}$ & inducing cell cycle arrest and autophagy & [110] \\
\hline myricetin & in vivo & $100 \mathrm{mg} / \mathrm{kg}$ & $\begin{array}{l}\text { suppressing chemical-induced } \\
\text { carcinogenesis }\end{array}$ & [117] \\
\hline galangin & in vitro & $10-134 \mu \mathrm{M}$ & $\begin{array}{l}\text { inhibiting chemical-induced cell invasion, } \\
\text { metastasis, promoting ER stress }\end{array}$ & {$[119,120]$} \\
\hline daidzein & in vitro & $200-600 \mu \mathrm{M}$ & inducing apoptosis & [127] \\
\hline genistein & in vivo & $50 \mathrm{mg} / \mathrm{kg}$ & suppressing the intrahepatic metastasis & [136] \\
\hline ellagic acid & in vivo & $30 \mathrm{mg} / \mathrm{kg}$ & $\begin{array}{l}\text { suppressing chemical-induced } \\
\text { carcinogenesis }\end{array}$ & [145] \\
\hline gallic acid & in vitro & $22.1-28.5 \mu \mathrm{g} / \mathrm{mL}$ & inducing apoptosis & [153] \\
\hline sesamin & in vitro & $25-125 \mu \mathrm{M}$ & $\begin{array}{l}\text { inducing apoptosis and cell cycle arrest } \\
\text { mediated by STAT3 }\end{array}$ & [163] \\
\hline
\end{tabular}


Table 3. Cont.

\begin{tabular}{|c|c|c|c|c|}
\hline Polyphenol & Study Type & Dose & Main Effects & References \\
\hline \multicolumn{5}{|l|}{ Liver Cancer } \\
\hline resveratrol & in vitro & $25-100 \mu \mathrm{M}$ & $\begin{array}{l}\text { inhibiting metastasis, decreasing } \\
\text { expression of } \mathrm{u}-\mathrm{PA} \text {, down-regulating the } \\
\text { SP-1 signaling pathway }\end{array}$ & [175] \\
\hline resveratrol & in vivo & $20 \mathrm{mg} / \mathrm{kg}$ & $\begin{array}{l}\text { suppressing chemical-induced } \\
\text { carcinogenesis }\end{array}$ & [176] \\
\hline \multicolumn{5}{|l|}{ Breast Cancer } \\
\hline anthocyanins & in vivo & $6 \mathrm{mg} / \mathrm{kg}$ & $\begin{array}{l}\text { suppressing the growth of } \\
\text { HER2-positive tumor }\end{array}$ & [32] \\
\hline $\begin{array}{c}\text { cyanidin-3- } \\
\text { O-sambubioside }\end{array}$ & in vitro & $1-30 \mu \mathrm{M}$ & inhibiting angiogenesis and invasion & [34] \\
\hline xanthohumol & in vitro & NA & $\begin{array}{l}\text { decreasing expression of CXCR4, inhibiting } \\
\text { cell invasion induced by CXCL12 }\end{array}$ & [42] \\
\hline xanthohumol & in vivo & 0.3 and $1.0 \mathrm{mg} / \mathrm{kg}$ & $\begin{array}{l}\text { blocking the estrogen singling pathway, } \\
\text { selectively suppressing the growth of } \\
\text { ER } \alpha \text {-positive breast cancer }\end{array}$ & [41] \\
\hline EGCG & in vitro & $1-40 \mu \mathrm{M}$ & $\begin{array}{l}\text { suppressing estrogen-induced cancer cell } \\
\text { proliferation, down-regulating ER } \alpha, \\
\text { inhibiting metastasis by restoring the } \\
\text { balance between MMP and TIMP }\end{array}$ & {$[52-54]$} \\
\hline procyanidins & in vitro & $25-100 \mu \mathrm{M}$ & $\begin{array}{l}\text { inducing apoptosis, reducing } \\
\text { invasion, angiogenesis }\end{array}$ & [59] \\
\hline naringenin & in vivo & $100 \mathrm{mg} / \mathrm{kg}$ & $\begin{array}{l}\text { suppressing lung metastases by the } \\
\text { host immunity }\end{array}$ & [66] \\
\hline hesperetin & in vitro & $40-200 \mu \mathrm{M}$ & $\begin{array}{l}\text { inducing apoptosis, ROS production and } \\
\text { activation of ASK1/JNK pathway, } \\
\text { suppressing glucose uptake }\end{array}$ & {$[69,70]$} \\
\hline apigenin & in vitro & $20-100 \mu \mathrm{M}$ & $\begin{array}{l}\text { suppressing growth and causing apoptosis } \\
\text { possibly mediated by the STAT3 } \\
\text { signaling pathway }\end{array}$ & [78] \\
\hline apigenin & in vivo & $5-25 \mathrm{mg} / \mathrm{kg}$ & $\begin{array}{l}\text { inducing cell cycle arrest through } \\
\text { epigenetic change }\end{array}$ & [79] \\
\hline chrysin & in vitro & $5-20 \mu \mathrm{M}$ & $\begin{array}{l}\text { inhibiting cancer cell invasion } \\
\text { and migration }\end{array}$ & [84] \\
\hline luteolin & in vitro & $10-40 \mu \mathrm{M}$ & $\begin{array}{l}\text { down-regulating ER } \alpha \text { expression, inducing } \\
\text { apoptosis and cell cycle arrest }\end{array}$ & [92] \\
\hline luteolin & in vivo & $\begin{array}{l}0.01 \%-0.05 \% \\
\text { in diet }\end{array}$ & reducing tumor burden & [93] \\
\hline quercetin & in vitro & $1-200 \mu \mathrm{M}$ & $\begin{array}{l}\text { inducing apoptosis, suppressing the insulin } \\
\text { receptor signaling and EMT }\end{array}$ & [100-102] \\
\hline quercetin & in vivo & $34 \mathrm{mg} / \mathrm{kg}$ & inhibiting angiogenesis & [103] \\
\hline kaempferol & in vitro & $100 \mu \mathrm{M}$ & $\begin{array}{l}\text { inducing apoptosis and suppressing } \\
\text { glucose uptake }\end{array}$ & {$[111,112]$} \\
\hline kaempferol & in vivo & $100 \mathrm{mg} / \mathrm{kg}$ & $\begin{array}{l}\text { preventing cancer development induced } \\
\text { by estrogen }\end{array}$ & [113] \\
\hline isorhamnetin & in vitro & $10-40 \mu \mathrm{M}$ & $\begin{array}{l}\text { inhibiting cancer cell adhesion, } \\
\text { migration, invasion }\end{array}$ & [122] \\
\hline daidzein & in vitro & $3-50 \mu \mathrm{M}$ & $\begin{array}{l}\text { decreasing invasion, MMP-2 expression, } \\
\text { up-regulating proto-oncogene BRF2 in } \\
\text { ER-positive cancer cells }\end{array}$ & {$[128,129]$} \\
\hline genistein & in vitro & $5-20 \mu \mathrm{M}$ & $\begin{array}{l}\text { inducing apoptosis, cell cycle arrest, } \\
\text { increasing drug resistance }\end{array}$ & {$[10,137]$} \\
\hline genistein & in vivo & $\leq 500 \mathrm{ppm}$ & enhancing tumor growth & [140] \\
\hline ellagic acid & in vitro & $10-40 \mu \mathrm{g} / \mathrm{mL}$ & inducing cell cycle arrest & [143] \\
\hline
\end{tabular}


Table 3. Cont

\begin{tabular}{|c|c|c|c|c|}
\hline Polyphenol & Study Type & Dose & Main Effects & References \\
\hline \multicolumn{5}{|l|}{ Breast Cancer } \\
\hline ellagic acid & in vivo & $50-100 \mathrm{mg} / \mathrm{kg}$ & $\begin{array}{l}\text { suppressing tumor growth } \\
\text { and angiogenesis }\end{array}$ & [146] \\
\hline gallic acid & in vitro & $80.5 \mu \mathrm{M}$ & inducing apoptosis & [150] \\
\hline SDG & in vivo & $100 \mathrm{ppm}$ in diet & $\begin{array}{l}\text { normalizing some biomarkers changed } \\
\text { by carcinogen }\end{array}$ & [160] \\
\hline enterolactone & in vitro & $261.9 \pm 10.5 \mu \mathrm{M}$ & $\begin{array}{l}\text { modulating expression of genes involved in } \\
\text { cell proliferation and cell cycle }\end{array}$ & [161] \\
\hline sesamin & in vitro & $1-100 \mu \mathrm{M}$ & $\begin{array}{l}\text { inducing apoptosis and inhibiting the } \\
\text { pro-angiogenic activity of macrophages }\end{array}$ & [162] \\
\hline pterostilbene & in vitro & $25-75 \mu \mathrm{M}$ & inducing apoptosis & [181] \\
\hline pterostilbene & in vivo & $10 \mathrm{mg} / \mathrm{kg}$ & suppressing tumor growth and metastasis & [182] \\
\hline \multicolumn{5}{|l|}{ Prostate Cancer } \\
\hline delphinidin & in vitro & 3-90 $\mu \mathrm{M}$ & inducing apoptosis and cell cycle arrest & [31] \\
\hline xanthohumol & in vivo & $50 \mu \mathrm{g} /$ mouse & suppressing tumor growth and progression & [43] \\
\hline EGCG & in vivo & $1 \mathrm{mg} 3 \times /$ week & $\begin{array}{l}\text { antagonizing androgen, suppressing } \\
\text { tumor growth }\end{array}$ & [55] \\
\hline hesperetin & in vitro & $40-90 \mu \mathrm{M}$ & $\begin{array}{l}\text { inducing apoptosis, inhibiting the } \\
\text { NF- } \kappa B \text { pathway }\end{array}$ & [71] \\
\hline apigenin & in vivo & $\begin{array}{c}20 \text { and } \\
50 \mu \mathrm{g} / \text { mouse }\end{array}$ & $\begin{array}{l}\text { suppressing tumor growth, } \\
\text { angiogenesis, metastasis }\end{array}$ & [81] \\
\hline luteolin & in vitro & $30 \mu \mathrm{M}$ & $\begin{array}{l}\text { inducing apoptosis, cell cycle arrest, } \\
\text { inhibiting invasion }\end{array}$ & [94] \\
\hline quercetin & in vivo & $200 \mathrm{mg} / \mathrm{kg}$ & $\begin{array}{l}\text { inhibiting carcinogenesis induced by } \\
\text { hormone and carcinogen }\end{array}$ & [104] \\
\hline genistein & in vitro & $0.5-50 \mu \mathrm{M}$ & $\begin{array}{l}\text { different effects dependent on } \\
\text { androgen receptor }\end{array}$ & [141] \\
\hline ellagic acid & in vitro & $10-100 \mu \mathrm{M}$ & $\begin{array}{l}\text { inducing apoptosis, inhibiting cell } \\
\text { invasion, motility }\end{array}$ & {$[147,148]$} \\
\hline gallic acid & in vitro & $25-200 \mu \mathrm{M}$ & $\begin{array}{l}\text { provoking DNA damage, down-regulating } \\
\text { DNA repair genes, invasion and migration }\end{array}$ & {$[154,155]$} \\
\hline ferulic acid & in vitro & $300-500 \mu \mathrm{M}$ & inducing apoptosis and cell cycle arrest & [158] \\
\hline sesamin & in vivo & $10 \mathrm{mg} / \mathrm{kg}$ & suppressed tumor growth induced by LPS & [164] \\
\hline resveratrol & in vitro & $25-100 \mu \mathrm{M}$ & inducing autophagy-mediated cell death & [177] \\
\hline resveratrol & in vivo & $30 \mathrm{mg} / \mathrm{kg}$ & $\begin{array}{l}\text { inducing apoptosis, suppressing } \\
\text { angiogenesis and metastasis }\end{array}$ & [178] \\
\hline pterostilbene & in vitro & $80 \mu \mathrm{M}$ & inducing apoptosis and cell cycle arrest & [184] \\
\hline pterostilbene & in vivo & $50 \mathrm{mg} / \mathrm{kg}$ & suppressing tumor growth & [185] \\
\hline piceatannol & in vitro & 25 and $50 \mu \mathrm{M}$ & inducing apoptosis and cell cycle arrest & [187] \\
\hline piceatannol & in vivo & $20 \mathrm{mg} / \mathrm{kg}$ & suppressing lung metastasis & [188] \\
\hline \multicolumn{5}{|l|}{ Cervical Cancer } \\
\hline hesperetin & in vitro & $650 \mu \mathrm{M}$ & inducing apoptosis & [72] \\
\hline quercetin & in vitro & $110.38 \mu \mathrm{M}$ & inducing apoptosis and cell cycle arrest & [106] \\
\hline genistein & in vitro & $100 \mu \mathrm{M}$ & $\begin{array}{l}\text { inducing apoptosis, cell cycle arrest, } \\
\text { suppressing cell migration }\end{array}$ & [142] \\
\hline gallic acid & in vitro & $10-40 \mu \mathrm{g} / \mathrm{mL}$ & $\begin{array}{l}\text { decreasing cell proliferation, } \\
\text { invasion, angiogenesis }\end{array}$ & [156] \\
\hline ferulic acid & in vitro & $10 \mu \mathrm{g} / \mathrm{mL}$ & enhancing efficacy of radiotherapy & [159] \\
\hline resveratrol & in vitro & $150-250 \mu \mathrm{M}$ & inducing apoptosis and cell cycle arrest & [179] \\
\hline
\end{tabular}

${ }^{1} \mathrm{NA}$, stands for not available. 


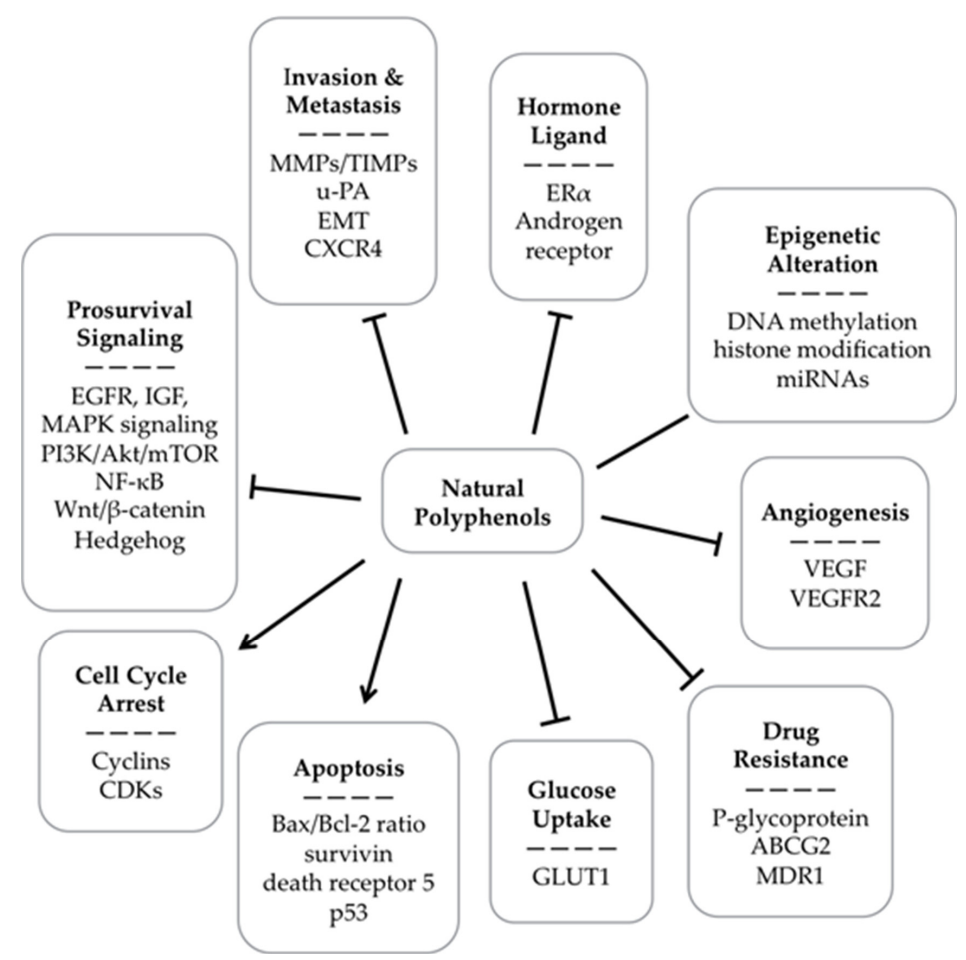

Figure 11. Mechanisms of the anticancer activities of natural polyphenols $\rightarrow$ stands for activation, - for regulation, $\perp$ for inhibition.

Table 4. The anti-cancer stem cell effects of polyphenols.

\begin{tabular}{|c|c|c|c|c|c|}
\hline Compound & Cancer & Study Type & Dose & Effect & References \\
\hline \multirow{2}{*}{ EGCG } & $\begin{array}{l}\text { colorectal } \\
\text { cancer }\end{array}$ & in vivo & $100 \mu \mathrm{M}$ & $\begin{array}{l}\text { Inhibiting tumor growth of } \\
\text { spheroid-derived cancer stem } \\
\text { cell xenografts }\end{array}$ & [50] \\
\hline & breast cancer & in vivo & $16.5 \mathrm{mg} / \mathrm{kg}$ & $\begin{array}{l}\text { decreasing tumor growth, the } \\
\text { expression of VEGF-D and } \\
\text { peritumoral lymphatic } \\
\text { vessel density }\end{array}$ & [51] \\
\hline \multirow[b]{2}{*}{ genistein } & gastric cancer & in vivo & $1.5 \mathrm{mg} / \mathrm{kg}$ & decreasing tumor weight and size & [131] \\
\hline & breast cancer & in vivo & $20-50 \mathrm{mg} / \mathrm{kg}$ & $\begin{array}{l}\text { targeting breast cancer stem cells } \\
\text { to reduce the growth of xenograft } \\
\text { tumors and inhibiting } \\
\text { the Hedgehog-Gli1 } \\
\text { signaling pathway }\end{array}$ & [138] \\
\hline resveratrol & breast cancer & in vivo & $100 \mathrm{mg} / \mathrm{kg}$ & $\begin{array}{l}\text { inhibited the Wnt / } \beta \text {-catenin } \\
\text { signaling pathway, tumor growth } \\
\text { and cancer stem cells }\end{array}$ & [174] \\
\hline pterostilbene & breast cancer & in vitro & $25 \mu \mathrm{M}$ & $\begin{array}{l}\text { decreasing cancer stem cells and } \\
\text { drug resistance }\end{array}$ & [183] \\
\hline
\end{tabular}


Table 5. The bioavailability of some natural polyphenols.

\begin{tabular}{|c|c|c|c|c|}
\hline Compound & Subject & Treatment & Urine Concentration & Plasm Concentration \\
\hline anthocyanins & human & black berries $200 \mathrm{~g}(960 \mu \mathrm{mol}) *$ & $\begin{array}{c}\text { total urinary excretion } \\
\text { of anthocyanin } \\
\text { metabolites } 0.160 \%\end{array}$ & NA \\
\hline EGCG & human & $2 \mathrm{mg} / \mathrm{kg}$ & NA & $\begin{array}{l}\operatorname{mean} C \max 0.09 \mu \mathrm{mol} / \mathrm{L} \text {, } \\
\text { Tmax } 2 \mathrm{~h}\end{array}$ \\
\hline naringenin & human & $\begin{array}{l}\text { fresh orange segments } 150 \mathrm{~g}(11.8 \\
\mathrm{mg} / 150 \mathrm{~g} \text { fresh weight })^{*}\end{array}$ & $\begin{array}{l}\text { mean urinary } \\
\text { excretion } 12.5 \%\end{array}$ & $\begin{array}{l}\operatorname{mean} C \max 0.08 \mu \mathrm{mol} / \mathrm{L}, \\
\text { Tmax } 5.88 \mathrm{~h}\end{array}$ \\
\hline hesperetin & human & $\begin{array}{l}\text { fresh orange segments } 150 \mathrm{~g}(79.7 \\
\mathrm{mg} / 150 \mathrm{~g} \text { fresh weight })\end{array}$ & $\begin{array}{l}\text { mean urinary } \\
\text { excretion } 4.53 \%\end{array}$ & $\begin{array}{l}\operatorname{mean} \mathrm{Cmax} 0.09 \mu \mathrm{mol} / \mathrm{L}, \\
\operatorname{Tmax} 7 \mathrm{~h}\end{array}$ \\
\hline quercetin & human & $\begin{array}{l}\text { dry shallot skin } 1.4 \mathrm{mg} / \mathrm{kg} \\
(4.93 \mu \mathrm{mol} / \mathrm{g} \text { fresh weight })^{*}\end{array}$ & NA & $\begin{array}{l}\operatorname{mean} \mathrm{Cmax} 3.95 \mu \mathrm{mol} / \mathrm{L}, \\
\operatorname{Tmax} 2.78 \mathrm{~h}\end{array}$ \\
\hline isorhamnetin & rat & $0.25 \mathrm{mg} / \mathrm{kg}$ & NA & $\begin{array}{l}\operatorname{mean} \mathrm{Cmax} 0.18 \mu \mathrm{mol} / \mathrm{L} \text {, } \\
\text { Tmax } 8 \mathrm{~h}\end{array}$ \\
\hline daidzein & human & $\begin{array}{l}\text { soy milk } 750 \mathrm{~mL} / \text { day } \\
(5.4 \mathrm{mg} / 250 \mathrm{~mL})^{*}\end{array}$ & $\begin{array}{l}148.35 \mu \mathrm{mol} / 24 \mathrm{~h} \\
\text { after } 5 \text { days }\end{array}$ & $196.1 \mathrm{nmol} / \mathrm{L}$ after 5 days \\
\hline genistein & human & $\begin{array}{l}\text { soy milk } 750 \mathrm{~mL} / \text { day } \\
(16.98 \mathrm{mg} / 250 \mathrm{~mL})^{*}\end{array}$ & $\begin{array}{l}2077.7 \mu \mathrm{mol} / 24 \mathrm{~h} \\
\text { after } 5 \text { days }\end{array}$ & $797.04 \mathrm{nmol} / \mathrm{L}$ after 5 days \\
\hline ellagic acid & human & $\begin{array}{c}\text { freeze-dried black raspberry } \\
45 \mathrm{~g} / \text { day }(0.3 \mathrm{mg} / \mathrm{g} \text { dry weight })\end{array}$ & NA & $\begin{array}{l}\operatorname{mean} C \max 0.01 \mu \mathrm{mol} / \mathrm{L}, \\
\operatorname{Tmax} 1.98 \mathrm{~h}\end{array}$ \\
\hline gallic acid & human & $\begin{array}{c}\text { grape skin extract } 18 \mathrm{~g}(0.7 \mathrm{mg} / \mathrm{g} \\
\text { dry weight })^{*}\end{array}$ & $5.9 \mu \mathrm{mol}$ after $24 \mathrm{~h}$ & NA \\
\hline ferulic acid & rat & $5.15 \mathrm{mg} / \mathrm{kg}$ & $\begin{array}{l}\text { mean urinary } \\
\text { excretion } 43.4 \%\end{array}$ & $\begin{array}{l}\operatorname{mean} C \max 1.68 \mu \mathrm{mol} / \mathrm{L}, \\
\operatorname{Tmax} 1 \mathrm{~h}\end{array}$ \\
\hline resveratrol & human & $1 \mathrm{mg} / \mathrm{kg}$ trans-resveratrol & $\begin{array}{l}\text { mean urinary } \\
\text { excretion } 26 \%\end{array}$ & $0.75 \mu \mathrm{g} / \mathrm{mL}$ after $1.5 \mathrm{~h}$ \\
\hline
\end{tabular}

* Indicates content of the compound in food; NA, stands for not available.

\section{Clinical Trials}

Though numerous studies have demonstrated that natural polyphenol could be potential candidates for anticancer therapy, clinical studies in this area are relatively few and the therapeutic efficacy is sometimes non-significant. A review of early clinical investigations on polyphenolic phytochemicals suggested tea polyphenols could be used for the prevention of premalignancy, but evidence was less convincing for curcumin and soy isoflavones [192]. Table 6 summarized some clinical evidence about the use of natural polyphenol in cancer treatment. The clinical trials in this section were identified from the PubMed database using the MeSH term "neoplasms" combined with "polyphenols".

Table 6. Summary of clinical trials with polyphenols in various cancers.

\begin{tabular}{llll}
\hline \multicolumn{1}{c}{ Subject } & \multicolumn{1}{c}{ Treatment } & \multicolumn{1}{c}{ Outcome } & References \\
\hline $\begin{array}{l}\text { 54 patients with localized } \\
\text { prostate cancer }\end{array}$ & $\begin{array}{l}\text { synthetic genistein }(30 \mathrm{mg}) \\
\text { daily for 3-6 weeks }\end{array}$ & $\begin{array}{l}\text { decreasing level of serum } \\
\text { prostate specific antigen (PSA) }\end{array}$ & [193] \\
\hline $\begin{array}{l}158 \text { men aged 50-75 with } \\
\text { rising prostate } \\
\text { specific antigen }\end{array}$ & $\begin{array}{l}\text { isoflavone }(60 \mathrm{mg}) \text { daily for } \\
12 \text { months }\end{array}$ & $\begin{array}{l}\text { reducing prostate cancer } \\
\text { incidence for patients aged 65 } \\
\text { or more }\end{array}$ & [194] \\
$\begin{array}{l}\text { 86 patients with localized } \\
\text { prostate cancer }\end{array}$ & $\begin{array}{l}\text { soy isoflavone }(80 \mathrm{mg} \text { total } \\
\text { isoflavones, 51 mg aglucon } \\
\text { units) daily for 6 weeks }\end{array}$ & $\begin{array}{l}\text { no significant change in serum } \\
\text { hormone levels, total } \\
\text { cholesterol, or PSA }\end{array}$ & [195] \\
\hline $\begin{array}{l}\text { 10 breast cancer patients } \\
\text { undergoing radiotherapy }\end{array}$ & $\begin{array}{l}\text { EGCG (400 mg) thrice daily } \\
\text { for 2-8 weeks }\end{array}$ & $\begin{array}{l}\text { enhancing efficacy } \\
\text { of radiotherapy }\end{array}$ & [196] \\
\hline
\end{tabular}


Table 6. Cont.

\begin{tabular}{|c|c|c|c|}
\hline Subject & Treatment & Outcome & References \\
\hline $\begin{array}{l}147 \text { patients with } \\
\text { prostate cancer }\end{array}$ & $\begin{array}{l}\text { flaxseed }(30 \mathrm{mg}) \text { daily for } \\
30 \text { days }\end{array}$ & $\begin{array}{l}\text { significant inverse association } \\
\text { between total urinary } \\
\text { enterolignans and } \\
\text { enterolactone and Ki67 in the } \\
\text { tumor tissue }\end{array}$ & [197] \\
\hline $\begin{array}{l}87 \text { patients with resected } \\
\text { colorectal cancer } \\
\text { or polypectomy }\end{array}$ & $\begin{array}{l}\text { flavonoid mixture ( } 20 \mathrm{mg} \\
\text { apigenin and } 20 \mathrm{mg} \text { EGCG) } \\
\text { for 3-4 years }\end{array}$ & $\begin{array}{l}\text { reducing recurrence rate of } \\
\text { colon neoplasia in patients } \\
\text { with resected colon cancer }\end{array}$ & [198] \\
\hline $\begin{array}{l}5 \text { familial adenomatous } \\
\text { polyposis patients } \\
\text { with colectomy }\end{array}$ & $\begin{array}{l}\text { curcumin }(480 \mathrm{mg}) \text { and } \\
\text { quercetin }(20 \mathrm{mg}) \text { thrice } \\
\text { daily for } 6 \text { months }\end{array}$ & $\begin{array}{l}\text { reducing polyp number and } \\
\text { size from baseline without } \\
\text { appreciable toxicity }\end{array}$ & [199] \\
\hline $\begin{array}{l}85 \text { patients with } \\
\text { prostate cancer }\end{array}$ & $\begin{array}{l}\text { isoflavones }(40 \mathrm{mg}) \text { and } \\
\text { curcumin }(100 \mathrm{mg}) \text { daily for } \\
6 \text { months }\end{array}$ & decreasing level of serum PSA & [200] \\
\hline $\begin{array}{l}44 \text { smokers with } 8 \text { or more } \\
\text { aberrant crypt foci }\end{array}$ & $\begin{array}{l}\text { curcumin ( } 2 \text { or } 4 \mathrm{~g}) \text { daily for } \\
30 \text { days }\end{array}$ & $\begin{array}{l}\text { decreasing number of aberrant } \\
\text { crypt foci }\end{array}$ & [201] \\
\hline $\begin{array}{l}126 \text { patients with } \\
\text { colorectal cancer }\end{array}$ & $\begin{array}{l}\text { curcumin }(360 \mathrm{mg}) \text { thrice } \\
\text { daily for } 10-30 \text { days }\end{array}$ & $\begin{array}{l}\text { increasing body weight and } \\
\text { expression of p53, suppressing } \\
\text { serum level of TNF- } \alpha\end{array}$ & [202] \\
\hline
\end{tabular}

\section{Conclusions}

The epidemiological studies about the relationship between dietary polyphenol consumption and cancer risks yielded different results. The difficult in assessing intake of dietary polyphenols and the diversity of polyphenols might contribute to the inconsistent results. On the other hand, the vast majority of laboratory studies supported anticancer activities of natural polyphenols, such as anthocyanins, EGCG, resveratrol and curcumin. The mechanisms of action mainly included modulation of molecular events and signaling pathways associated with cell survival, proliferation, differentiation, migration, angiogenesis, hormone activities, detoxification enzymes, immune responses, etc. Besides, the anticancer effects of polyphenol varied with cancer types, cell lines and doses. It is of note that some polyphenols, such as genistein and daidzein, have been suggested to have adverse effects on hormone-related cancer. Therefore, the use of these polyphenols in cancer treatment should be cautious. In addition, clinical trials about the anticancer actions of polyphenol are limited. In the future, more epidemiological studies employing biomarkers of polyphenols are needed to assess the impact of dietary polyphenols on cancer risks. Besides, the anticancer activities of more polyphenols need to be assessed and compared, and the mechanisms of action require further study. Larger, randomized clinical trials need to be carried out to provide more reliable evidence. Additionally, the bioavailability of polyphenols should be evaluated and improved. Special attention should be paid to the safety of polyphenols.

Acknowledgments: This work was supported by the National Natural Science Foundation of China (No. 81372976), Key Project of Guangdong Provincial Science and Technology Program (No. 2014B020205002), and the Hundred-Talents Scheme of Sun Yat-sen University.

Author Contributions: Yue Zhou, Sha Li and Hua-Bin Li conceived this paper; Yue Zhou, Jie Zheng, Ya Li and Dong-Ping Xu wrote this paper; and Sha Li, Yu-Ming Chen and Hua-Bin Li revised the paper.

Conflicts of Interest: The authors declare no conflict of interest.

\section{References}

1. WHO /Cancer. Available online: http://www.who.int/mediacentre/factsheets/fs297/en/ (accessed on 17 May 2016). 
2. Manach, C.; Scalbert, A.; Morand, C.; Remesy, C.; Jimenez, L. Polyphenols: Food sources and bioavailability. Am. J. Clin. Nutr. 2004, 79, 727-747. [PubMed]

3. Zhou, Y.; Li, Y.; Zhou, T.; Zheng, J.; Li, S.; Li, H.B. Dietary natural products for prevention and treatment of liver cancer. Nutrients 2016, 8, 156. [CrossRef] [PubMed]

4. Fu, L.; Xu, B.T.; Xu, X.R.; Qin, X.S.; Gan, R.Y.; Li, H.B. Antioxidant capacities and total phenolic contents of 56 wild fruits from South China. Molecules 2010, 15, 8602-8617. [CrossRef] [PubMed]

5. Deng, G.F.; Lin, X.; Xu, X.R.; Gao, L.; Xie, J.; Li, H.B. Antioxidant capacities and total phenolic contents of 56 vegetables. J. Funct. Foods 2013, 5, 260-266. [CrossRef]

6. Neveu, V.; Perez-Jimenez, J.; Vos, F.; Crespy, V.; du Chaffaut, L.; Mennen, L.; Knox, C.; Eisner, R.; Cruz, J.; Wishart, D.; et al. Phenol-Explorer: An online comprehensive database on polyphenol contents in foods. Database 2010, 2010, 24. [CrossRef] [PubMed]

7. Kausar, H.; Jeyabalan, J.; Aqil, F.; Chabba, D.; Sidana, J.; Singh, I.P.; Gupta, R.C. Berry anthocyanidins synergistically suppress growth and invasive potential of human non-small-cell lung cancer cells. Cancer Lett. 2012, 325, 54-62. [CrossRef] [PubMed]

8. Li, A.N.; Li, S.; Zhang, Y.; Xu, X.R.; Chen, Y.; Li, H.B. Resources and biological activities of Natural Polyphenols. Nutrients 2014, 6, 6020-6047. [CrossRef] [PubMed]

9. Shi, J.; Liu, F.; Zhang, W.; Liu, X.; Lin, B.; Tang, X. Epigallocatechin-3-gallate inhibits nicotine-induced migration and invasion by the suppression of angiogenesis and epithelial-mesenchymal transition in non-small cell lung cancer cells. Oncol. Rep. 2015, 33, 2972-2980. [CrossRef] [PubMed]

10. Rigalli, J.P.; Tocchetti, G.N.; Arana, M.R.; Villanueva, S.S.; Catania, V.A.; Theile, D.; Ruiz, M.L.; Weiss, J. The phytoestrogen genistein enhances multidrug resistance in breast cancer cell lines by translational regulation of $\mathrm{ABC}$ transporters. Cancer Lett. 2016, 376, 165-172. [CrossRef] [PubMed]

11. Wang, H.; Zhang, H.; Tang, L.; Chen, H.; Wu, C.; Zhao, M.; Yang, Y.; Chen, X.; Liu, G. Resveratrol inhibits TGF-beta1-induced epithelial-to-mesenchymal transition and suppresses lung cancer invasion and metastasis. Toxicology 2013, 303, 139-146. [CrossRef] [PubMed]

12. Li, F.; Li, S.; Li, H.B.; Deng, G.F.; Ling, W.H.; Xu, X.R. Antiproliferative activities of tea and herbal infusions. Food Funct. 2013, 4, 530-538. [CrossRef] [PubMed]

13. Li, F.; Li, S.; Li, H.; Deng, G.; Ling, W.; Wu, S.; Xu, X.; Chen, F. Antiproliferative activity of peels, pulps and seeds of 61 fruits. J. Funct. Foods 2013, 5, 1298-1309. [CrossRef]

14. Christensen, K.Y.; Naidu, A.; Parent, M.E.; Pintos, J.; Abrahamowicz, M.; Siemiatycki, J.; Koushik, A. The risk of lung cancer related to dietary intake of flavonoids. Nutr. Cancer 2012, 64, 964-974. [CrossRef] [PubMed]

15. Woo, H.D.; Lee, J.; Choi, I.J.; Kim, C.G.; Lee, J.Y.; Kwon, O.; Kim, J. Dietary flavonoids and gastric cancer risk in a Korean population. Nutrients 2014, 6, 4961-4973. [CrossRef] [PubMed]

16. Petrick, J.L.; Steck, S.E.; Bradshaw, P.T.; Trivers, K.F.; Abrahamson, P.E.; Engel, L.S.; He, K.; Chow, W.H.; Mayne, S.T.; Risch, H.A.; et al. Dietary intake of flavonoids and oesophageal and gastric cancer: Incidence and survival in the United States of America (USA). Br. J. Cancer 2015, 112, 1291-1300. [CrossRef] [PubMed]

17. Tse, G.; Eslick, G.D. Soy and isoflavone consumption and risk of gastrointestinal cancer: A systematic review and meta-analysis. Eur. J. Nutr. 2016, 55, 63-73. [CrossRef] [PubMed]

18. Zamora-Ros, R.; Not, C.; Guino, E.; Lujan-Barroso, L.; Garcia, R.M.; Biondo, S.; Salazar, R.; Moreno, V. Association between habitual dietary flavonoid and lignan intake and colorectal cancer in a Spanish case-control study (the Bellvitge Colorectal Cancer Study). Cancer Causes Control 2013, 24, 549-557. [CrossRef] [PubMed]

19. Nimptsch, K.; Zhang, X.; Cassidy, A.; Song, M.; O’Reilly, E.J.; Lin, J.H.; Pischon, T.; Rimm, E.B.; Willett, W.C.; Fuchs, C.S.; et al. Habitual intake of flavonoid subclasses and risk of colorectal cancer in 2 large prospective cohorts. Am. J. Clin. Nutr. 2016, 103, 184-191. [CrossRef] [PubMed]

20. Wang, Z.J.; Ohnaka, K.; Morita, M.; Toyomura, K.; Kono, S.; Ueki, T.; Tanaka, M.; Kakeji, Y.; Maehara, Y.; Okamura, T.; et al. Dietary polyphenols and colorectal cancer risk: The Fukuoka colorectal cancer study. World J. Gastroenterol. 2013, 19, 2683-2690. [CrossRef] [PubMed]

21. Zamora-Ros, R.; Agudo, A.; Lujan-Barroso, L.; Romieu, I.; Ferrari, P.; Knaze, V.; Bueno-de-Mesquita, H.B.; Leenders, M.; Travis, R.C.; Navarro, C.; et al. Dietary flavonoid and lignan intake and gastric adenocarcinoma risk in the European Prospective Investigation into Cancer and Nutrition (EPIC) study. Am. J. Clin. Nutr. 2012, 96, 1398-1408. [CrossRef] [PubMed] 
22. Zamora-Ros, R.; Fedirko, V.; Trichopoulou, A.; Gonzalez, C.A.; Bamia, C.; Trepo, E.; Nothlings, U.; Duarte-Salles, T.; Serafini, M.; Bredsdorff, L.; et al. Dietary flavonoid, lignan and antioxidant capacity and risk of hepatocellular carcinoma in the European prospective investigation into cancer and nutrition study. Int. J. Cancer 2013, 133, 2429-2443. [CrossRef] [PubMed]

23. Hui, C.; Qi, X.; Qianyong, Z.; Xiaoli, P.; Jundong, Z.; Mantian, M. Flavonoids, flavonoid subclasses and breast cancer risk: A meta-analysis of epidemiologic studies. PLoS ONE 2013, 8, e54318. [CrossRef] [PubMed]

24. Chen, M.; Rao, Y.; Zheng, Y.; Wei, S.; Li, Y.; Guo, T.; Yin, P. Association between soy isoflavone intake and breast cancer risk for pre- and post-menopausal women: A meta-analysis of epidemiological studies. PLOS ONE 2014, 9, e89288. [CrossRef] [PubMed]

25. Xie, Q.; Chen, M.L.; Qin, Y.; Zhang, Q.Y.; Xu, H.X.; Zhou, Y.; Mi, M.T.; Zhu, J.D. Isoflavone consumption and risk of breast cancer: A dose-response meta-analysis of observational studies. Asia Pac. J. Clin. Nutr. 2013, 22, 118-127. [PubMed]

26. Wang, Y.; Gapstur, S.M.; Gaudet, M.M.; Peterson, J.J.; Dwyer, J.T.; McCullough, M.L. Evidence for an association of dietary flavonoid intake with breast cancer risk by estrogen receptor status is limited. J. Nutr. 2014, 144, 1603-1611. [CrossRef] [PubMed]

27. Geybels, M.S.; Verhage, B.A.; Arts, I.C.; van Schooten, F.J.; Goldbohm, R.A.; van den Brandt, P.A. Dietary flavonoid intake, black tea consumption, and risk of overall and advanced stage prostate cancer. Am. J. Epidemiol. 2013, 177, 1388-1398. [CrossRef] [PubMed]

28. Wang, Y.; Stevens, V.L.; Shah, R.; Peterson, J.J.; Dwyer, J.T.; Gapstur, S.M.; McCullough, M.L. Dietary flavonoid and proanthocyanidin intakes and prostate cancer risk in a prospective cohort of US men. Am. J. Epidemiol. 2014, 179, 974-986. [CrossRef] [PubMed]

29. Crozier, A.; Jaganath, I.B.; Clifford, M.N. Dietary phenolics: Chemistry, bioavailability and effects on health. Nat. Prod. Rep. 2009, 26, 1001-1043. [CrossRef] [PubMed]

30. Yun, J.M.; Afaq, F.; Khan, N.; Mukhtar, H. Delphinidin, an anthocyanidin in pigmented fruits and vegetables, induces apoptosis and cell cycle arrest in human colon cancer HCT116 cells. Mol. Carcinog. 2009, 48, 260-270. [CrossRef] [PubMed]

31. Bin, H.B.; Asim, M.; Siddiqui, I.A.; Adhami, V.M.; Murtaza, I.; Mukhtar, H. Delphinidin, a dietary anthocyanidin in pigmented fruits and vegetables: A new weapon to blunt prostate cancer growth. Cell Cycle 2008, 7, 3320-3326.

32. Liu, W.; Xu, J.; Wu, S.; Liu, Y.; Yu, X.; Chen, J.; Tang, X.; Wang, Z.; Zhu, X.; Li, X. Selective anti-proliferation of HER2-positive breast cancer cells by anthocyanins identified by high-throughput screening. PLoS ONE 2013, 8, e81586. [CrossRef] [PubMed]

33. Ho, M.L.; Chen, P.N.; Chu, S.C.; Kuo, D.Y.; Kuo, W.H.; Chen, J.Y.; Hsieh, Y.S. Peonidin 3-glucoside inhibits lung cancer metastasis by downregulation of proteinases activities and MAPK pathway. Nutr. Cancer 2010, 62, 505-516. [CrossRef] [PubMed]

34. Lee, S.J.; Hong, S.; Yoo, S.H.; Kim, G.W. Cyanidin-3-O-sambubioside from Acanthopanax sessiliflorus fruit inhibits metastasis by downregulating MMP-9 in breast cancer cells MDA-MB-231. Planta Med. 2013, 79, 1636-1640. [CrossRef] [PubMed]

35. Cvorovic, J.; Tramer, F.; Granzotto, M.; Candussio, L.; Decorti, G.; Passamonti, S. Oxidative stress-based cytotoxicity of delphinidin and cyanidin in colon cancer cells. Arch. Biochem. Biophys. 2010, 501, 151-157. [CrossRef] [PubMed]

36. Jing, P.; Bomser, J.A.; Schwartz, S.J.; He, J.; Magnuson, B.A.; Giusti, M.M. Structure-function relationships of anthocyanins from various anthocyanin-rich extracts on the inhibition of colon cancer cell growth. J. Agric. Food Chem. 2008, 56, 9391-9398. [CrossRef] [PubMed]

37. Yong, W.K.; Abd, M.S. Xanthohumol induces growth inhibition and apoptosis in ca ski human cervical cancer cells. Evid.-Based Complement. Altern. Med. 2015, 2015, 921306. [CrossRef] [PubMed]

38. Yong, W.K.; Ho, Y.F.; Malek, S.N. Xanthohumol induces apoptosis and S phase cell cycle arrest in A549 non-small cell lung cancer cells. Pharmacogn. Mag. 2015, 11, S275-S283. [PubMed]

39. Zhao, X.; Jiang, K.; Liang, B.; Huang, X. Anticancer effect of xanthohumol induces growth inhibition and apoptosis of human liver cancer through NF-kappaB/p53-apoptosis signaling pathway. Oncol. Rep. 2016, 35, 669-675. [PubMed] 
40. Kunnimalaiyaan, S.; Sokolowski, K.M.; Balamurugan, M.; Gamblin, T.C.; Kunnimalaiyaan, M. Xanthohumol inhibits Notch signaling and induces apoptosis in hepatocellular carcinoma. PLoS ONE 2015, 10, e127464. [CrossRef] [PubMed]

41. Yoshimaru, T.; Komatsu, M.; Tashiro, E.; Imoto, M.; Osada, H.; Miyoshi, Y.; Honda, J.; Sasa, M.; Katagiri, T. Xanthohumol suppresses oestrogen-signalling in breast cancer through the inhibition of BIG3-PHB2 interactions. Sci. Rep. 2014, 4, 7355. [CrossRef] [PubMed]

42. Wang, Y.; Chen, Y.; Wang, J.; Chen, J.; Aggarwal, B.B.; Pang, X.; Liu, M. Xanthohumol, a prenylated chalcone derived from hops, suppresses cancer cell invasion through inhibiting the expression of CXCR4 chemokine receptor. Curr. Mol. Med. 2012, 12, 153-162. [CrossRef] [PubMed]

43. Vene, R.; Benelli, R.; Minghelli, S.; Astigiano, S.; Tosetti, F.; Ferrari, N. Xanthohumol impairs human prostate cancer cell growth and invasion and diminishes the incidence and progression of advanced tumors in TRAMP mice. Mol. Med. 2012, 18, 1292-1302. [CrossRef] [PubMed]

44. Deng, Y.T.; Lin, J.K. EGCG inhibits the invasion of highly invasive CL1-5 lung cancer cells through suppressing MMP-2 expression via JNK signaling and induces G2/M arrest. J. Agric. Food Chem. 2011, 59, 13318-13327. [CrossRef] [PubMed]

45. Onoda, C.; Kuribayashi, K.; Nirasawa, S.; Tsuji, N.; Tanaka, M.; Kobayashi, D.; Watanabe, N. (-)-Epigallocatechin-3-gallate induces apoptosis in gastric cancer cell lines by down-regulating survivin expression. Int. J. Oncol. 2011, 38, 1403-1408. [PubMed]

46. Tanaka, T.; Ishii, T.; Mizuno, D.; Mori, T.; Yamaji, R.; Nakamura, Y.; Kumazawa, S.; Nakayama, T.; Akagawa, M. (-)-Epigallocatechin-3-gallate suppresses growth of AZ521 human gastric cancer cells by targeting the DEAD-box RNA helicase p68. Free Radic. Biol. Med. 2011, 50, 1324-1335. [CrossRef] [PubMed]

47. Cerezo-Guisado, M.I.; Zur, R.; Lorenzo, M.J.; Risco, A.; Martin-Serrano, M.A.; Alvarez-Barrientos, A.; Cuenda, A.; Centeno, F. Implication of Akt, ERK1/2 and alternative p38MAPK signalling pathways in human colon cancer cell apoptosis induced by green tea EGCG. Food Chem. Toxicol. 2015, 84, 125-132. [CrossRef] [PubMed]

48. Thakur, V.S.; Deb, G.; Babcook, M.A.; Gupta, S. Plant phytochemicals as epigenetic modulators: Role in cancer chemoprevention. AAPS J. 2014, 16, 151-163. [CrossRef] [PubMed]

49. Saldanha, S.N.; Kala, R.; Tollefsbol, T.O. Molecular mechanisms for inhibition of colon cancer cells by combined epigenetic-modulating epigallocatechin gallate and sodium butyrate. Exp. Cell Res. 2014, 324, 40-53. [CrossRef] [PubMed]

50. Toden, S.; Tran, H.M.; Tovar-Camargo, O.A.; Okugawa, Y.; Goel, A. Epigallocatechin-3-gallate targets cancer stem-like cells and enhances 5-fluorouracil chemosensitivity in colorectal cancer. Oncotarget 2016, 7, 16158-16171. [CrossRef] [PubMed]

51. Mineva, N.D.; Paulson, K.E.; Naber, S.P.; Yee, A.S.; Sonenshein, G.E. Epigallocatechin-3-gallate inhibits stem-like inflammatory breast cancer cells. PLOS ONE 2013, 8, e73464.

52. Tu, S.H.; Ku, C.Y.; Ho, C.T.; Chen, C.S.; Huang, C.S.; Lee, C.H.; Chen, L.C.; Pan, M.H.; Chang, H.W.; Chang, C.H.; et al. Tea polyphenol (-)-epigallocatechin-3-gallate inhibits nicotine- and estrogen-induced alpha9-nicotinic acetylcholine receptor upregulation in human breast cancer cells. Mol. Nutr. Food Res. 2011, 55, 455-466. [CrossRef] [PubMed]

53. De Amicis, F.; Russo, A.; Avena, P.; Santoro, M.; Vivacqua, A.; Bonofiglio, D.; Mauro, L.; Aquila, S.; Tramontano, D.; Fuqua, S.A.; et al. In vitro mechanism for downregulation of ER-alpha expression by epigallocatechin gallate in ER+/PR+ human breast cancer cells. Mol. Nutr. Food Res. 2013, 57, 840-853. [CrossRef] [PubMed]

54. Deb, G.; Thakur, V.S.; Limaye, A.M.; Gupta, S. Epigenetic induction of tissue inhibitor of matrix metalloproteinase-3 by green tea polyphenols in breast cancer cells. Mol. Carcinog. 2015, 54, 485-499. [CrossRef] [PubMed]

55. Siddiqui, I.A.; Asim, M.; Hafeez, B.B.; Adhami, V.M.; Tarapore, R.S.; Mukhtar, H. Green tea polyphenol EGCG blunts androgen receptor function in prostate cancer. FASEB J. 2011, 25, 1198-1207. [CrossRef] [PubMed]

56. Kin, R.; Kato, S.; Kaneto, N.; Sakurai, H.; Hayakawa, Y.; Li, F.; Tanaka, K.; Saiki, I.; Yokoyama, S. Procyanidin C1 from Cinnamomi Cortex inhibits TGF-beta-induced epithelial-to-mesenchymal transition in the A549 lung cancer cell line. Int. J. Oncol. 2013, 43, 1901-1906. [PubMed] 
57. Choy, Y.Y.; Fraga, M.; Mackenzie, G.G.; Waterhouse, A.L.; Cremonini, E.; Oteiza, P.I. The PI3K/Akt pathway is involved in procyanidin-mediated suppression of human colorectal cancer cell growth. Mol. Carcinog. 2016. [CrossRef] [PubMed]

58. Gorlach, S.; Wagner, W.; Podsedek, A.; Szewczyk, K.; Koziolkiewicz, M.; Dastych, J. Procyanidins from Japanese quince (Chaenomeles japonica) fruit induce apoptosis in human colon cancer Caco-2 cells in a degree of polymerization-dependent manner. Nutr. Cancer 2011, 63, 1348-1360. [CrossRef] [PubMed]

59. Lewandowska, U.; Szewczyk, K.; Owczarek, K.; Hrabec, Z.; Podsedek, A.; Sosnowska, D.; Hrabec, E. Procyanidins from evening primrose (Oenothera paradoxa) defatted seeds inhibit invasiveness of breast cancer cells and modulate the expression of selected genes involved in angiogenesis, metastasis, and apoptosis. Nutr. Cancer 2013, 65, 1219-1231. [CrossRef] [PubMed]

60. Jin, C.Y.; Park, C.; Hwang, H.J.; Kim, G.Y.; Choi, B.T.; Kim, W.J.; Choi, Y.H. Naringenin up-regulates the expression of death receptor 5 and enhances TRAIL-induced apoptosis in human lung cancer A549 cells. Mol. Nutr. Food Res. 2011, 55, 300-309. [CrossRef] [PubMed]

61. Bao, L.; Liu, F.; Guo, H.B.; Li, Y.; Tan, B.B.; Zhang, W.X.; Peng, Y.H. Naringenin inhibits proliferation, migration, and invasion as well as induces apoptosis of gastric cancer SGC7901 cell line by downregulation of AKT pathway. Tumour Biol. 2016. [CrossRef] [PubMed]

62. Song, H.M.; Park, G.H.; Eo, H.J.; Jeong, J.B. Naringenin-Mediated ATF3 Expression Contributes to Apoptosis in Human Colon Cancer. Biomol. Ther. (Seoul) 2016, 24, 140-146. [CrossRef] [PubMed]

63. Yen, H.R.; Liu, C.J.; Yeh, C.C. Naringenin suppresses TPA-induced tumor invasion by suppressing multiple signal transduction pathways in human hepatocellular carcinoma cells. Chem. Biol. Interact. 2015, 235, 1-9. [CrossRef] [PubMed]

64. Arul, D.; Subramanian, P. Naringenin (citrus flavonone) induces growth inhibition, cell cycle arrest and apoptosis in human hepatocellular carcinoma cells. Pathol. Oncol. Res. 2013, 19, 763-770. [CrossRef] [PubMed]

65. Kim, S.; Park, T.I. Naringenin: A partial agonist on estrogen receptor in T47D-KBluc breast cancer cells. Int. J. Clin. Exp. Med. 2013, 6, 890-899. [PubMed]

66. Qin, L.; Jin, L.; Lu, L.; Lu, X.; Zhang, C.; Zhang, F.; Liang, W. Naringenin reduces lung metastasis in a breast cancer resection model. Protein Cell 2011, 2, 507-516. [CrossRef] [PubMed]

67. Zhang, J.; Wu, D.; Vikash; Song, J.; Wang, J.; Yi, J.; Dong, W. Hesperetin induces the apoptosis of gastric cancer cells via activating mitochondrial pathway by increasing reactive oxygen species. Dig. Dis. Sci. 2015, 60, 2985-2995. [CrossRef] [PubMed]

68. Aranganathan, S.; Nalini, N. Antiproliferative efficacy of hesperetin (citrus flavanoid) in 1,2-dimethylhydrazineinduced colon cancer. Phytother. Res. 2013, 27, 999-1005. [CrossRef] [PubMed]

69. Palit, S.; Kar, S.; Sharma, G.; Das, P.K. Hesperetin induces apoptosis in breast carcinoma by triggering accumulation of ROS and activation of ASK1/JNK pathway. J. Cell. Physiol. 2015, 230, 1729-1739. [CrossRef] [PubMed]

70. Yang, Y.; Wolfram, J.; Boom, K.; Fang, X.; Shen, H.; Ferrari, M. Hesperetin impairs glucose uptake and inhibits proliferation of breast cancer cells. Cell Biochem. Funct. 2013, 31, 374-379. [CrossRef] [PubMed]

71. Sambantham, S.; Radha, M.; Paramasivam, A.; Anandan, B.; Malathi, R.; Chandra, S.R.; Jayaraman, G. Molecular mechanism underlying hesperetin-induced apoptosis by in silico analysis and in prostate cancer PC-3 cells. Asian Pac. J. Cancer Prev. 2013, 14, 4347-4352. [CrossRef] [PubMed]

72. Alshatwi, A.A.; Ramesh, E.; Periasamy, V.S.; Subash-Babu, P. The apoptotic effect of hesperetin on human cervical cancer cells is mediated through cell cycle arrest, death receptor, and mitochondrial pathways. Fundam. Clin. Pharmacol. 2013, 27, 581-592. [CrossRef] [PubMed]

73. Zhu, Y.; Wu, J.; Li, S.; Wang, X.; Liang, Z.; Xu, X.; Xu, X.; Hu, Z.; Lin, Y.; Chen, H.; et al. Apigenin inhibits migration and invasion via modulation of epithelial mesenchymal transition in prostate cancer. Mol. Med. Rep. 2015, 11, 1004-1008. [CrossRef] [PubMed]

74. Lu, H.F.; Chie, Y.J.; Yang, M.S.; Lu, K.W.; Fu, J.J.; Yang, J.S.; Chen, H.Y.; Hsia, T.C.; Ma, C.Y.; Ip, S.W.; et al. Apigenin induces apoptosis in human lung cancer $\mathrm{H} 460$ cells through caspase- and mitochondria-dependent pathways. Hum. Exp. Toxicol. 2011, 30, 1053-1061. [CrossRef] [PubMed]

75. Chen, J.; Chen, J.; Li, Z.; Liu, C.; Yin, L. The apoptotic effect of apigenin on human gastric carcinoma cells through mitochondrial signal pathway. Tumor Biol. 2014, 35, 7719-7726. [CrossRef] [PubMed] 
76. Kuo, C.H.; Weng, B.C.; Wu, C.C.; Yang, S.F.; Wu, D.C.; Wang, Y.C. Apigenin has anti-atrophic gastritis and anti-gastric cancer progression effects in Helicobacter pylori-infected Mongolian gerbils. J. Ethnopharmacol. 2014, 151, 1031-1039. [CrossRef] [PubMed]

77. Chunhua, L.; Donglan, L.; Xiuqiong, F.; Lihua, Z.; Qin, F.; Yawei, L.; Liang, Z.; Ge, W.; Linlin, J.; Ping, Z.; et al. Apigenin up-regulates transgelin and inhibits invasion and migration of colorectal cancer through decreased phosphorylation of AKT. J. Nutr. Biochem. 2013, 24, 1766-1775. [CrossRef] [PubMed]

78. Seo, H.S.; Jo, J.K.; Ku, J.M.; Choi, H.S.; Choi, Y.K.; Woo, J.K.; Kim, H.I.; Kang, S.Y.; Lee, K.M.; Nam, K.W.; et al. Induction of caspase-dependent extrinsic apoptosis by apigenin through inhibition of signal transducer and activator of transcription 3 (STAT3) signalling in HER2-overexpressing BT-474 breast cancer cells. Biosci. Rep. 2015, 35, e00276. [CrossRef] [PubMed]

79. Tseng, T.H.; Chien, M.H.; Lin, W.L.; Wen, Y.C.; Chow, J.M.; Chen, C.K.; Kuo, T.C.; Lee, W.J. Inhibition of MDA-MB-231 breast cancer cell proliferation and tumor growth by apigenin through induction of G2/M arrest and histone $\mathrm{H} 3$ acetylation-mediated p21 expression. Environ. Toxicol. 2016. [CrossRef] [PubMed]

80. Pandey, M.; Kaur, P.; Shukla, S.; Abbas, A.; Fu, P.; Gupta, S. Plant flavone apigenin inhibits HDAC and remodels chromatin to induce growth arrest and apoptosis in human prostate cancer cells: In vitro and in vivo study. Mol. Carcinog. 2012, 51, 952-962. [CrossRef] [PubMed]

81. Shukla, S.; Bhaskaran, N.; Babcook, M.A.; Fu, P.; Maclennan, G.T.; Gupta, S. Apigenin inhibits prostate cancer progression in TRAMP mice via targeting PI3K/Akt/FoxO pathway. Carcinogenesis 2014, 35, 452-460. [CrossRef] [PubMed]

82. Yang, B.; Huang, J.; Xiang, T.; Yin, X.; Luo, X.; Huang, J.; Luo, F.; Li, H.; Li, H.; Ren, G. Chrysin inhibits metastatic potential of human triple-negative breast cancer cells by modulating matrix metalloproteinase-10, epithelial to mesenchymal transition, and PI3K/Akt signaling pathway. J. Appl. Toxicol. 2014, 34, 105-112. [CrossRef] [PubMed]

83. Shao, J.J.; Zhang, A.P.; Qin, W.; Zheng, L.; Zhu, Y.F.; Chen, X. AMP-activated protein kinase (AMPK) activation is involved in chrysin-induced growth inhibition and apoptosis in cultured A549 lung cancer cells. Biochem. Biophys. Res. Commun. 2012, 423, 448-453. [CrossRef] [PubMed]

84. Ronnekleiv-Kelly, S.M.; Nukaya, M.; Diaz-Diaz, C.J.; Megna, B.W.; Carney, P.R.; Geiger, P.G.; Kennedy, G.D. Aryl hydrocarbon receptor-dependent apoptotic cell death induced by the flavonoid chrysin in human colorectal cancer cells. Cancer Lett. 2016, 370, 91-99. [CrossRef] [PubMed]

85. Cai, X.; Ye, T.; Liu, C.; Lu, W.; Lu, M.; Zhang, J.; Wang, M.; Cao, P. Luteolin induced G2 phase cell cycle arrest and apoptosis on non-small cell lung cancer cells. Toxicol. Vitro 2011, 25, 1385-1391. [CrossRef] [PubMed]

86. Choi, H.J.; Choi, H.J.; Chung, T.W.; Ha, K.T. Luteolin inhibits recruitment of monocytes and migration of Lewis lung carcinoma cells by suppressing chemokine (C-C motif) ligand 2 expression in tumor-associated macrophage. Biochem. Biophys. Res. Commun. 2016, 470, 101-106. [CrossRef] [PubMed]

87. Ruan, J.; Zhang, L.; Yan, L.; Liu, Y.; Yue, Z.; Chen, L.; Wang, A.Y.; Chen, W.; Zheng, S.; Wang, S.; et al. Inhibition of hypoxia-induced epithelial mesenchymal transition by luteolin in non-small cell lung cancer cells. Mol. Med. Rep. 2012, 6, 232-238. [PubMed]

88. Hong, Z.; Cao, X.; Li, N.; Zhang, Y.; Lan, L.; Zhou, Y.; Pan, X.; Shen, L.; Yin, Z.; Luo, L. Luteolin is effective in the non-small cell lung cancer model with L858R/T790M EGF receptor mutation and erlotinib resistance. Br. J. Pharmacol. 2014, 171, 2842-2853. [CrossRef] [PubMed]

89. Lu, J.; Li, G.; He, K.; Jiang, W.; Xu, C.; Li, Z.; Wang, H.; Wang, W.; Wang, H.; Teng, X.; et al. Luteolin exerts a marked antitumor effect in cMet-overexpressing patient-derived tumor xenograft models of gastric cancer. J. Transl. Med. 2015, 13, 42. [CrossRef] [PubMed]

90. Lim, D.Y.; Cho, H.J.; Kim, J.; Nho, C.W.; Lee, K.W.; Park, J.H. Luteolin decreases IGF-II production and downregulates insulin-like growth factor-I receptor signaling in HT-29 human colon cancer cells. BMC Gastroenterol. 2012, 12, 9. [CrossRef] [PubMed]

91. Abdel, H.L.; Di Vito, C.; Marfia, G.; Ferraretto, A.; Tringali, C.; Viani, P.; Riboni, L. Sphingosine Kinase 2 and Ceramide Transport as Key Targets of the Natural Flavonoid Luteolin to Induce Apoptosis in Colon Cancer Cells. PLoS ONE 2015, 10, e143384. [CrossRef] [PubMed]

92. Wang, L.M.; Xie, K.P.; Huo, H.N.; Shang, F.; Zou, W.; Xie, M.J. Luteolin inhibits proliferation induced by IGF-1 pathway dependent ERalpha in human breast cancer MCF-7 cells. Asian Pac. J. Cancer Prev. 2012, 13, 1431-1437. [CrossRef] [PubMed] 
93. Lee, E.J.; Oh, S.Y.; Sung, M.K. Luteolin exerts anti-tumor activity through the suppression of epidermal growth factor receptor-mediated pathway in MDA-MB-231 ER-negative breast cancer cells. Food Chem. Toxicol. 2012, 50, 4136-4143. [CrossRef] [PubMed]

94. Tsui, K.H.; Chung, L.C.; Feng, T.H.; Chang, P.L.; Juang, H.H. Upregulation of prostate-derived Ets factor by luteolin causes inhibition of cell proliferation and cell invasion in prostate carcinoma cells. Int. J. Cancer 2012, 130, 2812-2823. [CrossRef] [PubMed]

95. Zheng, S.Y.; Li, Y.; Jiang, D.; Zhao, J.; Ge, J.F. Anticancer effect and apoptosis induction by quercetin in the human lung cancer cell line A-549. Mol. Med. Rep. 2012, 5, 822-826. [CrossRef] [PubMed]

96. Wang, K.; Liu, R.; Li, J.; Mao, J.; Lei, Y.; Wu, J.; Zeng, J.; Zhang, T.; Wu, H.; Chen, L.; et al. Quercetin induces protective autophagy in gastric cancer cells: Involvement of Akt-mTOR- and hypoxia-induced factor 1alpha-mediated signaling. Autophagy 2011, 7, 966-978. [CrossRef] [PubMed]

97. Kim, H.S.; Wannatung, T.; Lee, S.; Yang, W.K.; Chung, S.H.; Lim, J.S.; Choe, W.; Kang, I.; Kim, S.S.; Ha, J. Quercetin enhances hypoxia-mediated apoptosis via direct inhibition of AMPK activity in HCT116 colon cancer. Apoptosis 2012, 17, 938-949. [CrossRef] [PubMed]

98. Velazquez, K.T.; Enos, R.T.; Narsale, A.A.; Puppa, M.J.; Davis, J.M.; Murphy, E.A.; Carson, J.A. Quercetin supplementation attenuates the progression of cancer cachexia in ApcMin/+ mice. J. Nutr. 2014, 144, 868-875. [CrossRef] [PubMed]

99. Dai, W.; Gao, Q.; Qiu, J.; Yuan, J.; Wu, G.; Shen, G. Quercetin induces apoptosis and enhances 5-FU therapeutic efficacy in hepatocellular carcinoma. Tumor Biol. 2015, 5, 6307-6313. [CrossRef] [PubMed]

100. Duo, J.; Ying, G.G.; Wang, G.W.; Zhang, L. Quercetin inhibits human breast cancer cell proliferation and induces apoptosis via Bcl-2 and Bax regulation. Mol. Med. Rep. 2012, 5, 1453-1456. [PubMed]

101. Wang, F.; Yang, Y. Quercetin suppresses insulin receptor signaling through inhibition of the insulin ligand-receptor binding and therefore impairs cancer cell proliferation. Biochem. Biophys. Res. Commun. 2014, 452, 1028-1033. [CrossRef] [PubMed]

102. Srinivasan, A.; Thangavel, C.; Liu, Y.; Shoyele, S.; Den, R.B.; Selvakumar, P.; Lakshmikuttyamma, A. Quercetin regulates beta-catenin signaling and reduces the migration of triple negative breast cancer. Mol. Carcinog. 2016, 55, 743-756. [CrossRef] [PubMed]

103. Zhao, X.; Wang, Q.; Yang, S.; Chen, C.; Li, X.; Liu, J.; Zou, Z.; Cai, D. Quercetin inhibits angiogenesis by targeting calcineurin in the xenograft model of human breast cancer. Eur. J. Pharmacol. 2016, 781, 60-68. [CrossRef] [PubMed]

104. Sharmila, G.; Athirai, T.; Kiruthiga, B.; Senthilkumar, K.; Elumalai, P.; Arunkumar, R.; Arunakaran, J. Chemopreventive effect of quercetin in MNU and testosterone induced prostate cancer of Sprague-Dawley rats. Nutr. Cancer 2014, 66, 38-46. [CrossRef] [PubMed]

105. Sharmila, G.; Bhat, F.A.; Arunkumar, R.; Elumalai, P.; Raja, S.P.; Senthilkumar, K.; Arunakaran, J. Chemopreventive effect of quercetin, a natural dietary flavonoid on prostate cancer in in vivo model. Clin. Nutr. 2014, 33, 718-726. [CrossRef] [PubMed]

106. Bishayee, K.; Ghosh, S.; Mukherjee, A.; Sadhukhan, R.; Mondal, J.; Khuda-Bukhsh, A.R. Quercetin induces cytochrome-c release and ROS accumulation to promote apoptosis and arrest the cell cycle in $\mathrm{G}_{2} / \mathrm{M}$, in cervical carcinoma: Signal cascade and drug-DNA interaction. Cell Prolif. 2013, 46, 153-163. [CrossRef] [PubMed]

107. Jo, E.; Park, S.J.; Choi, Y.S.; Jeon, W.K.; Kim, B.C. Kaempferol suppresses transforming growth factor-beta1-induced epithelial-to-mesenchymal transition and migration of A549 lung cancer cells by inhibiting Akt1-mediated phosphorylation of smad3 at threonine-179. Neoplasia 2015, 17, 525-537. [CrossRef] [PubMed]

108. Song, H.; Bao, J.; Wei, Y.; Chen, Y.; Mao, X.; Li, J.; Yang, Z.; Xue, Y. Kaempferol inhibits gastric cancer tumor growth: An in vitro and in vivo study. Oncol. Rep. 2015, 33, 868-874. [CrossRef] [PubMed]

109. Lee, H.S.; Cho, H.J.; Yu, R.; Lee, K.W.; Chun, H.S.; Park, J.H. Mechanisms underlying apoptosis-inducing effects of Kaempferol in HT-29 human colon cancer cells. Int. J. Mol. Sci. 2014, 15, 2722-2737. [CrossRef] [PubMed]

110. Huang, W.W.; Tsai, S.C.; Peng, S.F.; Lin, M.W.; Chiang, J.H.; Chiu, Y.J.; Fushiya, S.; Tseng, M.T.; Yang, J.S. Kaempferol induces autophagy through AMPK and AKT signaling molecules and causes G2/M arrest via downregulation of CDK1/cyclin B in SK-HEP-1 human hepatic cancer cells. Int. J. Oncol. 2013, 42, 2069-2077. [PubMed] 
111. Liao, W.; Chen, L.; Ma, X.; Jiao, R.; Li, X.; Wang, Y. Protective effects of kaempferol against reactive oxygen species-induced hemolysis and its antiproliferative activity on human cancer cells. Eur. J. Med. Chem. 2016, 114, 24-32. [CrossRef] [PubMed]

112. Azevedo, C.; Correia-Branco, A.; Araujo, J.R.; Guimaraes, J.T.; Keating, E.; Martel, F. The chemopreventive effect of the dietary compound kaempferol on the MCF-7 human breast cancer cell line is dependent on inhibition of glucose cellular uptake. Nutr. Cancer 2015, 67, 504-513. [CrossRef] [PubMed]

113. Kim, S.H.; Hwang, K.A.; Choi, K.C. Treatment with kaempferol suppresses breast cancer cell growth caused by estrogen and triclosan in cellular and xenograft breast cancer models. J. Nutr. Biochem. 2016, 28, 70-82. [CrossRef] [PubMed]

114. Li, C.; Zhao, Y.; Yang, D.; Yu, Y.; Guo, H.; Zhao, Z.; Zhang, B.; Yin, X. Inhibitory effects of kaempferol on the invasion of human breast carcinoma cells by downregulating the expression and activity of matrix metalloproteinase-9. Biochem. Cell. Biol. 2015, 93, 16-27. [CrossRef] [PubMed]

115. Feng, J.; Chen, X.; Wang, Y.; Du, Y.; Sun, Q.; Zang, W.; Zhao, G. Myricetin inhibits proliferation and induces apoptosis and cell cycle arrest in gastric cancer cells. Mol. Cell. Biochem. 2015, 408, 163-170. [CrossRef] [PubMed]

116. Kim, M.E.; Ha, T.K.; Yoon, J.H.; Lee, J.S. Myricetin induces cell death of human colon cancer cells via BAX/BCL2-dependent pathway. Anticancer Res. 2014, 34, 701-706. [PubMed]

117. Iyer, S.C.; Gopal, A.; Halagowder, D. Myricetin induces apoptosis by inhibiting P21 activated kinase 1 (PAK1) signaling cascade in hepatocellular carcinoma. Mol. Cell. Biochem. 2015, 407, 223-237. [CrossRef]

118. Kim, D.A.; Jeon, Y.K.; Nam, M.J. Galangin induces apoptosis in gastric cancer cells via regulation of ubiquitin carboxy-terminal hydrolase isozyme L1 and glutathione S-transferase P. Food Chem. Toxicol. 2012, 50, 684-688. [CrossRef] [PubMed]

119. Chien, S.T.; Shi, M.D.; Lee, Y.C.; Te, C.C.; Shih, Y.W. Galangin, a novel dietary flavonoid, attenuates metastatic feature via PKC/ERK signaling pathway in TPA-treated liver cancer HepG2 cells. Cancer Cell Int. 2015, 15, 15. [CrossRef] [PubMed]

120. Su, L.; Chen, X.; Wu, J.; Lin, B.; Zhang, H.; Lan, L.; Luo, H. Galangin inhibits proliferation of hepatocellular carcinoma cells by inducing endoplasmic reticulum stress. Food Chem. Toxicol. 2013, 62, 810-816. [CrossRef] [PubMed]

121. Hu, S.; Huang, L.; Meng, L.; Sun, H.; Zhang, W.; Xu, Y. Isorhamnetin inhibits cell proliferation and induces apoptosis in breast cancer via Akt and mitogenactivated protein kinase kinase signaling pathways. Mol. Med. Rep. 2015, 12, 6745-6751. [PubMed]

122. Li, C.; Yang, D.; Zhao, Y.; Qiu, Y.; Cao, X.; Yu, Y.; Guo, H.; Gu, X.; Yin, X. Inhibitory effects of isorhamnetin on the invasion of human breast carcinoma cells by downregulating the expression and activity of matrix metalloproteinase-2/9. Nutr. Cancer 2015, 67, 1191-1200. [CrossRef] [PubMed]

123. Li, Q.; Ren, F.Q.; Yang, C.L.; Zhou, L.M.; Liu, Y.Y.; Xiao, J.; Zhu, L.; Wang, Z.G. Anti-proliferation effects of isorhamnetin on lung cancer cells in vitro and in vivo. Asian Pac. J. Cancer Prev. 2015, 16, 3035-3042. [CrossRef] [PubMed]

124. Ramachandran, L.; Manu, K.A.; Shanmugam, M.K.; Li, F.; Siveen, K.S.; Vali, S.; Kapoor, S.; Abbasi, T.; Surana, R.; Smoot, D.T.; et al. Isorhamnetin inhibits proliferation and invasion and induces apoptosis through the modulation of peroxisome proliferator-activated receptor gamma activation pathway in gastric cancer. J. Biol. Chem. 2012, 287, 38028-38040. [CrossRef] [PubMed]

125. Li, C.; Yang, X.; Chen, C.; Cai, S.; Hu, J. Isorhamnetin suppresses colon cancer cell growth through the PI3KAktmTOR pathway. Mol. Med. Rep. 2014, 9, 935-940. [PubMed]

126. Saud, S.M.; Young, M.R.; Jones-Hall, Y.L.; Ileva, L.; Evbuomwan, M.O.; Wise, J.; Colburn, N.H.; Kim, Y.S.; Bobe, G. Chemopreventive activity of plant flavonoid isorhamnetin in colorectal cancer is mediated by oncogenic Src and beta-catenin. Cancer Res. 2013, 73, 5473-5484. [CrossRef] [PubMed]

127. Park, H.J.; Jeon, Y.K.; You, D.H.; Nam, M.J. Daidzein causes cytochrome c-mediated apoptosis via the Bcl-2 family in human hepatic cancer cells. Food Chem. Toxicol. 2013, 60, 542-549. [CrossRef] [PubMed]

128. Magee, P.J.; Allsopp, P.; Samaletdin, A.; Rowland, I.R. Daidzein, R-(+)equol and S-(-)equol inhibit the invasion of MDA-MB-231 breast cancer cells potentially via the down-regulation of matrix metalloproteinase-2. Eur. J. Nutr. 2014, 53, 345-350. [CrossRef] [PubMed] 
129. Koo, J.; Cabarcas-Petroski, S.; Petrie, J.L.; Diette, N.; White, R.J.; Schramm, L. Induction of proto-oncogene BRF2 in breast cancer cells by the dietary soybean isoflavone daidzein. BMC Cancer 2015, 15, 905. [CrossRef] [PubMed]

130. Tian, T.; Li, J.; Li, B.; Wang, Y.; Li, M.; Ma, D.; Wang, X. Genistein exhibits anti-cancer effects via down-regulating FoxM1 in H446 small-cell lung cancer cells. Tumor Biol. 2014, 35, 4137-4145. [CrossRef] [PubMed]

131. Huang, W.; Wan, C.; Luo, Q.; Huang, Z.; Luo, Q. Genistein-inhibited cancer stem cell-like properties and reduced chemoresistance of gastric cancer. Int. J. Mol. Sci. 2014, 15, 3432-3443. [CrossRef] [PubMed]

132. Qin, J.; Teng, J.; Zhu, Z.; Chen, J.; Huang, W.J. Genistein induces activation of the mitochondrial apoptosis pathway by inhibiting phosphorylation of Akt in colorectal cancer cells. Pharm. Biol. 2016, 54, 74-79. [CrossRef] [PubMed]

133. Xiao, X.; Liu, Z.; Wang, R.; Wang, J.; Zhang, S.; Cai, X.; Wu, K.; Bergan, R.C.; Xu, L.; Fan, D. Genistein suppresses FLT4 and inhibits human colorectal cancer metastasis. Oncotarget 2015, 6, 3225-3239. [CrossRef] [PubMed]

134. Luo, Y.; Wang, S.X.; Zhou, Z.Q.; Wang, Z.; Zhang, Y.G.; Zhang, Y.; Zhao, P. Apoptotic effect of genistein on human colon cancer cells via inhibiting the nuclear factor-kappa B (NF-kappaB) pathway. Tumor Biol. 2014, 35, 11483-11488. [CrossRef] [PubMed]

135. Lepri, S.R.; Zanelatto, L.C.; Da, S.P.; Sartori, D.; Ribeiro, L.R.; Mantovani, M.S. Effects of genistein and daidzein on cell proliferation kinetics in HT29 colon cancer cells: The expression of CTNNBIP1 (beta-catenin), APC (adenomatous polyposis coli) and BIRC5 (survivin). Hum. Cell 2014, 27, 78-84. [CrossRef] [PubMed]

136. Dai, W.; Wang, F.; He, L.; Lin, C.; Wu, S.; Chen, P.; Zhang, Y.; Shen, M.; Wu, D.; Wang, C.; et al. Genistein inhibits hepatocellular carcinoma cell migration by reversing the epithelial-mesenchymal transition: Partial mediation by the transcription factor NFAT1. Mol. Carcinog. 2015, 54, 301-311. [CrossRef] [PubMed]

137. Pan, H.; Zhou, W.; He, W.; Liu, X.; Ding, Q.; Ling, L.; Zha, X.; Wang, S. Genistein inhibits MDA-MB-231 triple-negative breast cancer cell growth by inhibiting NF-kappaB activity via the Notch-1 pathway. Int. J. Mol. Med. 2012, 30, 337-343. [PubMed]

138. Fan, P.; Fan, S.; Wang, H.; Mao, J.; Shi, Y.; Ibrahim, M.M.; Ma, W.; Yu, X.; Hou, Z.; Wang, B.; et al. Genistein decreases the breast cancer stem-like cell population through Hedgehog pathway. Stem Cell Res. Ther. 2013, 4, 146. [CrossRef] [PubMed]

139. Pons, D.G.; Nadal-Serrano, M.; Torrens-Mas, M.; Oliver, J.; Roca, P. The phytoestrogen genistein affects breast cancer cells treatment depending on the ERalpha/ERbeta ratio. J. Cell. Biochem. 2016, 117, 218-229. [CrossRef] [PubMed]

140. Andrade, J.E.; Ju, Y.H.; Baker, C.; Doerge, D.R.; Helferich, W.G. Long-term exposure to dietary sources of genistein induces estrogen-independence in the human breast cancer (MCF-7) xenograft model. Mol. Nutr. Food Res. 2015, 59, 413-423. [CrossRef] [PubMed]

141. Mahmoud, A.M.; Zhu, T.; Parray, A.; Siddique, H.R.; Yang, W.; Saleem, M.; Bosland, M.C. Differential effects of genistein on prostate cancer cells depend on mutational status of the androgen receptor. PLoS ONE 2013, 8, e78479. [CrossRef] [PubMed]

142. Hussain, A.; Harish, G.; Prabhu, S.A.; Mohsin, J.; Khan, M.A.; Rizvi, T.A.; Sharma, C. Inhibitory effect of genistein on the invasive potential of human cervical cancer cells via modulation of matrix metalloproteinase-9 and tissue inhibitors of matrix metalloproteinase-1 expression. Cancer Epidemiol. 2012, 36, e387-e393. [CrossRef] [PubMed]

143. Chen, H.S.; Bai, M.H.; Zhang, T.; Li, G.D.; Liu, M. Ellagic acid induces cell cycle arrest and apoptosis through TGF-beta/Smad3 signaling pathway in human breast cancer MCF-7 cells. Int. J. Oncol. 2015, 46, 1730-1738. [PubMed]

144. Yousef, A.I.; El-Masry, O.S.; Abdel, M.M. Impact of cellular genetic make-up on colorectal cancer cell lines response to ellagic acid: Implications of small interfering RNA. Asian Pac. J. Cancer Prev. 2016, 17, 743-748. [CrossRef] [PubMed]

145. Srigopalram, S.; Jayraaj, I.A.; Kaleeswaran, B.; Balamurugan, K.; Ranjithkumar, M.; Kumar, T.S.; Park, J.I.; Nou, I.S. Ellagic acid normalizes mitochondrial outer membrane permeabilization and attenuates inflammation-mediated cell proliferation in experimental liver cancer. Appl. Biochem. Biotechnol. 2014, 173, 2254-2266. [CrossRef] [PubMed] 
146. Wang, N.; Wang, Z.Y.; Mo, S.L.; Loo, T.Y.; Wang, D.M.; Luo, H.B.; Yang, D.P.; Chen, Y.L.; Shen, J.G.; Chen, J.P. Ellagic acid, a phenolic compound, exerts anti-angiogenesis effects via VEGFR-2 signaling pathway in breast cancer. Breast Cancer Res. Treat. 2012, 134, 943-955. [CrossRef] [PubMed]

147. Pitchakarn, P.; Chewonarin, T.; Ogawa, K.; Suzuki, S.; Asamoto, M.; Takahashi, S.; Shirai, T.; Limtrakul, P. Ellagic acid inhibits migration and invasion by prostate cancer cell lines. Asian Pac. J. Cancer Prev. 2013, 14, 2859-2863. [CrossRef] [PubMed]

148. Malik, A.; Afaq, S.; Shahid, M.; Akhtar, K.; Assiri, A. Influence of ellagic acid on prostate cancer cell proliferation: A caspase-dependent pathway. Asian Pac. J. Trop. Med. 2011, 4, 550-555. [CrossRef]

149. Subramanian, A.P.; Jaganathan, S.K.; Mandal, M.; Supriyanto, E.; Muhamad, I.I. Gallic acid induced apoptotic events in HCT-15 colon cancer cells. World J. Gastroenterol. 2016, 22, 3952-3961. [CrossRef] [PubMed]

150. Wang, K.; Zhu, X.; Zhang, K.; Zhu, L.; Zhou, F. Investigation of gallic acid induced anticancer effect in human breast carcinoma MCF-7 cells. J. Biochem. Mol. Toxicol. 2014, 28, 387-393. [CrossRef] [PubMed]

151. Ho, H.H.; Chang, C.S.; Ho, W.C.; Liao, S.Y.; Lin, W.L.; Wang, C.J. Gallic acid inhibits gastric cancer cells metastasis and invasive growth via increased expression of RhoB, downregulation of AKT/small GTPase signals and inhibition of NF-kappaB activity. Toxicol. Appl. Pharmacol. 2013, 266, 76-85. [CrossRef] [PubMed]

152. Russell, L.J.; Mazzio, E.; Badisa, R.B.; Zhu, Z.P.; Agharahimi, M.; Oriaku, E.T.; Goodman, C.B. Autoxidation of gallic acid induces ROS-dependent death in human prostate cancer LNCaP cells. Anticancer Res. 2012, 32, 1595-1602. [PubMed]

153. Sun, G.; Zhang, S.; Xie, Y.; Zhang, Z.; Zhao, W. Gallic acid as a selective anticancer agent that induces apoptosis in SMMC-7721 human hepatocellular carcinoma cells. Oncol. Lett. 2016, 11, 150-158. [CrossRef] [PubMed]

154. Liu, K.C.; Huang, A.C.; Wu, P.P.; Lin, H.Y.; Chueh, F.S.; Yang, J.S.; Lu, C.C.; Chiang, J.H.; Meng, M.; Chung, J.G. Gallic acid suppresses the migration and invasion of PC-3 human prostate cancer cells via inhibition of matrix metalloproteinase-2 and -9 signaling pathways. Oncol. Rep. 2011, 26, 177-184. [PubMed]

155. Liu, K.C.; Ho, H.C.; Huang, A.C.; Ji, B.C.; Lin, H.Y.; Chueh, F.S.; Yang, J.S.; Lu, C.C.; Chiang, J.H.; Meng, M.; et al. Gallic acid provokes DNA damage and suppresses DNA repair gene expression in human prostate cancer PC-3 cells. Environ. Toxicol. 2013, 28, 579-587. [CrossRef] [PubMed]

156. Zhao, B.; Hu, M. Gallic acid reduces cell viability, proliferation, invasion and angiogenesis in human cervical cancer cells. Oncol. Lett. 2013, 6, 1749-1755. [PubMed]

157. Sarwar, T.; Zafaryab, M.; Husain, M.A.; Ishqi, H.M.; Rehman, S.U.; Rizvi, M.M.; Tabish, M. Redox cycling of endogenous copper by ferulic acid leads to cellular DNA breakage and consequent cell death: A putative cancer chemotherapy mechanism. Toxicol. Appl. Pharmacol. 2015, 289, 251-261. [CrossRef] [PubMed]

158. Eroglu, C.; Secme, M.; Bagci, G.; Dodurga, Y. Assessment of the anticancer mechanism of ferulic acid via cell cycle and apoptotic pathways in human prostate cancer cell lines. Tumor Biol. 2015, 36, 9437-9446. [CrossRef] [PubMed]

159. Karthikeyan, S.; Kanimozhi, G.; Prasad, N.R.; Mahalakshmi, R. Radiosensitizing effect of ferulic acid on human cervical carcinoma cells in vitro. Toxicol. Vitro 2011, 25, 1366-1375. [CrossRef] [PubMed]

160. Delman, D.M.; Fabian, C.J.; Kimler, B.F.; Yeh, H.; Petroff, B.K. Effects of flaxseed lignan secoisolariciresinol diglucosideon preneoplastic biomarkers of cancer progression in a model of simultaneous breast and ovarian cancer development. Nutr. Cancer 2015, 67, 857-864. [CrossRef] [PubMed]

161. Xiong, X.Y.; Hu, X.J.; Li, Y.; Liu, C.M. Inhibitory effects of enterolactone on growth and metastasis in human breast cancer. Nutr. Cancer 2015, 67, 1324-1332. [CrossRef] [PubMed]

162. Lee, C.C.; Liu, K.J.; Wu, Y.C.; Lin, S.J.; Chang, C.C.; Huang, T.S. Sesamin inhibits macrophage-induced vascular endothelial growth factor and matrix metalloproteinase-9 expression and proangiogenic activity in breast cancer cells. Inflammation 2011, 34, 209-221. [CrossRef] [PubMed]

163. Deng, P.; Wang, C.; Chen, L.; Wang, C.; Du, Y.; Yan, X.; Chen, M.; Yang, G.; He, G. Sesamin induces cell cycle arrest and apoptosis through the inhibition of signal transducer and activator of transcription 3 signalling in human hepatocellular carcinoma cell line HepG2. Biol. Pharm. Bull. 2013, 36, 1540-1548. [CrossRef] [PubMed]

164. Xu, P.; Cai, F.; Liu, X.; Guo, L. Sesamin inhibits lipopolysaccharide-induced proliferation and invasion through the p38-MAPK and NF-kappaB signaling pathways in prostate cancer cells. Oncol. Rep. 2015, 33, 3117-3123. [PubMed] 
165. Ko, J.C.; Syu, J.J.; Chen, J.C.; Wang, T.J.; Chang, P.Y.; Chen, C.Y.; Jian, Y.T.; Jian, Y.J.; Lin, Y.W. Resveratrol enhances etoposide-induced cytotoxicity through down-regulating ERK1/2 and AKT-Mediated $\mathrm{X}$-ray repair cross-complement group 1 (XRCC1) protein expression in human non-small-cell lung cancer cells. Basic Clin. Pharmacol. Toxicol. 2015, 117, 383-391. [CrossRef] [PubMed]

166. Yang, Q.; Wang, B.; Zang, W.; Wang, X.; Liu, Z.; Li, W.; Jia, J. Resveratrol inhibits the growth of gastric cancer by inducing G1 phase arrest and senescence in a Sirt1-dependent manner. PLoS ONE 2013, 8, e70627. [CrossRef] [PubMed]

167. Wang, Z.; Li, W.; Meng, X.; Jia, B. Resveratrol induces gastric cancer cell apoptosis via reactive oxygen species, but independent of sirtuin1. Clin. Exp. Pharmacol. Physiol. 2012, 39, 227-232. [CrossRef]

168. Miki, H.; Uehara, N.; Kimura, A.; Sasaki, T.; Yuri, T.; Yoshizawa, K.; Tsubura, A. Resveratrol induces apoptosis via ROS-triggered autophagy in human colon cancer cells. Int. J. Oncol. 2012, 40, 1020-1028. [PubMed]

169. Colin, D.J.; Limagne, E.; Ragot, K.; Lizard, G.; Ghiringhelli, F.; Solary, E.; Chauffert, B.; Latruffe, N.; Delmas, D. The role of reactive oxygen species and subsequent DNA-damage response in the emergence of resistance towards resveratrol in colon cancer models. Cell Death Dis. 2014, 5, e1533. [CrossRef] [PubMed]

170. Demoulin, B.; Hermant, M.; Castrogiovanni, C.; Staudt, C.; Dumont, P. Resveratrol induces DNA damage in colon cancer cells by poisoning topoisomerase II and activates the ATM kinase to trigger p53-dependent apoptosis. Toxicol. Vitro 2015, 29, 1156-1165. [CrossRef] [PubMed]

171. Wang, Z.; Zhang, L.; Ni, Z.; Sun, J.; Gao, H.; Cheng, Z.; Xu, J.; Yin, P. Resveratrol induces AMPK-dependent MDR1 inhibition in colorectal cancer HCT116/L-OHP cells by preventing activation of NF-kappaB signaling and suppressing cAMP-responsive element transcriptional activity. Tumor Biol. 2015, 36, 9499-9510. [CrossRef] [PubMed]

172. Saud, S.M.; Li, W.; Morris, N.L.; Matter, M.S.; Colburn, N.H.; Kim, Y.S.; Young, M.R. Resveratrol prevents tumorigenesis in mouse model of Kras activated sporadic colorectal cancer by suppressing oncogenic Kras expression. Carcinogenesis 2014, 35, 2778-2786. [CrossRef] [PubMed]

173. Aires, V.; Limagne, E.; Cotte, A.K.; Latruffe, N.; Ghiringhelli, F.; Delmas, D. Resveratrol metabolites inhibit human metastatic colon cancer cells progression and synergize with chemotherapeutic drugs to induce cell death. Mol. Nutr. Food Res. 2013, 57, 1170-1181. [CrossRef] [PubMed]

174. Fu, Y.; Chang, H.; Peng, X.; Bai, Q.; Yi, L.; Zhou, Y.; Zhu, J.; Mi, M. Resveratrol inhibits breast cancer stem-like cells and induces autophagy via suppressing Wnt/beta-catenin signaling pathway. PLoS ONE 2014, 9, e102535.

175. Yeh, C.B.; Hsieh, M.J.; Lin, C.W.; Chiou, H.L.; Lin, P.Y.; Chen, T.Y.; Yang, S.F. The antimetastatic effects of resveratrol on hepatocellular carcinoma through the downregulation of a metastasis-associated protease by SP-1 modulation. PLoS ONE 2013, 8, e56661. [CrossRef] [PubMed]

176. Rajasekaran, D.; Elavarasan, J.; Sivalingam, M.; Ganapathy, E.; Kumar, A.; Kalpana, K.; Sakthisekaran, D. Resveratrol interferes with $N$-nitrosodiethylamine-induced hepatocellular carcinoma at early and advanced stages in male Wistar rats. Mol. Med. Rep. 2011, 4, 1211-1217. [PubMed]

177. Selvaraj, S.; Sun, Y.; Sukumaran, P.; Singh, B.B. Resveratrol activates autophagic cell death in prostate cancer cells via downregulation of STIM1 and the mTOR pathway. Mol. Carcinog. 2015, 5, 818-831. [CrossRef] [PubMed]

178. Ganapathy, S.; Chen, Q.; Singh, K.P.; Shankar, S.; Srivastava, R.K. Resveratrol enhances antitumor activity of TRAIL in prostate cancer xenografts through activation of FOXO transcription factor. PLoS ONE 2010, 5, e15627. [CrossRef] [PubMed]

179. Garcia-Zepeda, S.P.; Garcia-Villa, E.; Diaz-Chavez, J.; Hernandez-Pando, R.; Gariglio, P. Resveratrol induces cell death in cervical cancer cells through apoptosis and autophagy. Eur. J. Cancer Prev. 2013, 22, 577-584. [CrossRef] [PubMed]

180. Sun, Y.; Wu, X.; Cai, X.; Song, M.; Zheng, J.; Pan, C.; Qiu, P.; Zhang, L.; Zhou, S.; Tang, Z.; et al. Identification of pinostilbene as a major colonic metabolite of pterostilbene and its inhibitory effects on colon cancer cells. Mol. Nutr. Food Res. 2016. [CrossRef] [PubMed]

181. Moon, D.; McCormack, D.; McDonald, D.; McFadden, D. Pterostilbene induces mitochondrially derived apoptosis in breast cancer cells in vitro. J. Surg. Res. 2013, 180, 208-215. [CrossRef] [PubMed] 
182. Su, C.M.; Lee, W.H.; Wu, A.T.; Lin, Y.K.; Wang, L.S.; Wu, C.H.; Yeh, C.T. Pterostilbene inhibits triple-negative breast cancer metastasis via inducing microRNA-205 expression and negatively modulates epithelial-to-mesenchymal transition. J. Nutr. Biochem. 2015, 26, 675-685. [CrossRef] [PubMed]

183. Wu, C.H.; Hong, B.H.; Ho, C.T.; Yen, G.C. Targeting cancer stem cells in breast cancer: Potential anticancer properties of 6-shogaol and pterostilbene. J. Agric. Food Chem. 2015, 63, 2432-2441. [CrossRef] [PubMed]

184. Lin, V.C.; Tsai, Y.C.; Lin, J.N.; Fan, L.L.; Pan, M.H.; Ho, C.T.; Wu, J.Y.; Way, T.D. Activation of AMPK by pterostilbene suppresses lipogenesis and cell-cycle progression in 553 positive and negative human prostate cancer cells. J. Agric. Food Chem. 2012, 60, 6399-6407. [CrossRef] [PubMed]

185. Dhar, S.; Kumar, A.; Rimando, A.M.; Zhang, X.; Levenson, A.S. Resveratrol and pterostilbene epigenetically restore PTEN expression by targeting oncomiRs of the miR-17 family in prostate cancer. Oncotarget 2015, 6, 27214-27226. [CrossRef] [PubMed]

186. Zhang, H.; Jia, R.; Wang, C.; Hu, T.; Wang, F. Piceatannol promotes apoptosis via up-regulation of microRNA-129 expression in colorectal cancer cell lines. Biochem. Biophys. Res. Commun. 2014, 452, 775-781. [CrossRef] [PubMed]

187. Hsieh, T.C.; Lin, C.Y.; Lin, H.Y.; Wu, J.M. AKT/mTOR as novel targets of polyphenol piceatannol possibly contributing to inhibition of proliferation of cultured prostate cancer cells. ISRN Urol. 2012, 2012, 272697. [CrossRef] [PubMed]

188. Kwon, G.T.; Jung, J.I.; Song, H.R.; Woo, E.Y.; Jun, J.G.; Kim, J.K.; Her, S.; Park, J.H. Piceatannol inhibits migration and invasion of prostate cancer cells: Possible mediation by decreased interleukin- 6 signaling. J. Nutr. Biochem. 2012, 23, 228-238. [CrossRef] [PubMed]

189. Devassy, J.G.; Nwachukwu, I.D.; Jones, P.J. Curcumin and cancer: Barriers to obtaining a health claim. Nutr. Rev. 2015, 73, 155-165. [CrossRef] [PubMed]

190. Vallianou, N.G.; Evangelopoulos, A.; Schizas, N.; Kazazis, C. Potential anticancer properties and mechanisms of action of curcumin. Anticancer Res. 2015, 35, 645-651. [PubMed]

191. Shanmugam, M.; Rane, G.; Kanchi, M.; Arfuso, F.; Chinnathambi, A.; Zayed, M.; Alharbi, S.; Tan, B.; Kumar, A.; Sethi, G. The Multifaceted Role of Curcumin in Cancer Prevention and Treatment. Molecules 2015, 20, 2728-2769. [CrossRef] [PubMed]

192. Thomasset, S.C.; Berry, D.P.; Garcea, G.; Marczylo, T.; Steward, W.P.; Gescher, A.J. Dietary polyphenolic phytochemicals-Promising cancer chemopreventive agents in humans? A review of their clinical properties. Int. J. Cancer 2007, 120, 451-458. [CrossRef] [PubMed]

193. Lazarevic, B.; Boezelijn, G.; Diep, L.M.; Kvernrod, K.; Ogren, O.; Ramberg, H.; Moen, A.; Wessel, N.; Berg, R.E.; Egge-Jacobsen, W.; et al. Efficacy and safety of short-term genistein intervention in patients with localized prostate cancer prior to radical prostatectomy: A randomized, placebo-controlled, double-blind Phase 2 clinical trial. Nutr. Cancer 2011, 63, 889-898. [CrossRef] [PubMed]

194. Miyanaga, N.; Akaza, H.; Hinotsu, S.; Fujioka, T.; Naito, S.; Namiki, M.; Takahashi, S.; Hirao, Y.; Horie, S.; Tsukamoto, T.; et al. Prostate cancer chemoprevention study: An investigative randomized control study using purified isoflavones in men with rising prostate-specific antigen. Cancer Sci. 2012, 103, 125-130. [CrossRef] [PubMed]

195. Hamilton-Reeves, J.M.; Banerjee, S.; Banerjee, S.K.; Holzbeierlein, J.M.; Thrasher, J.B.; Kambhampati, S.; Keighley, J.; Van Veldhuizen, P. Short-term soy isoflavone intervention in patients with localized prostate cancer: A randomized, double-blind, placebo-controlled trial. PLoS ONE 2013, 8, e68331.

196. Zhang, G.; Wang, Y.; Zhang, Y.; Wan, X.; Li, J.; Liu, K.; Wang, F.; Liu, K.; Liu, Q.; Yang, C.; et al. Anti-cancer activities of tea epigallocatechin-3-gallate in breast cancer patients under radiotherapy. Curr. Mol. Med. 2012, 12, 163-176. [CrossRef] [PubMed]

197. Azrad, M.; Vollmer, R.T.; Madden, J.; Dewhirst, M.; Polascik, T.J.; Snyder, D.C.; Ruffin, M.T.; Moul, J.W.; Brenner, D.E.; Demark-Wahnefried, W. Flaxseed-derived enterolactone is inversely associated with tumor cell proliferation in men with localized prostate cancer. J. Med. Food 2013, 16, 357-360. [CrossRef] [PubMed]

198. Hoensch, H.; Groh, B.; Edler, L.; Kirch, W. Prospective cohort comparison of flavonoid treatment in patients with resected colorectal cancer to prevent recurrence. World J. Gastroenterol. 2008, 14, 2187-2193. [CrossRef] [PubMed]

199. Cruz-Correa, M.; Shoskes, D.A.; Sanchez, P.; Zhao, R.; Hylind, L.M.; Wexner, S.D.; Giardiello, F.M. Combination treatment with curcumin and quercetin of adenomas in familial adenomatous polyposis. Clin. Gastroenterol. Hepatol. 2006, 4, 1035-1038. [CrossRef] [PubMed] 
200. Ide, H.; Tokiwa, S.; Sakamaki, K.; Nishio, K.; Isotani, S.; Muto, S.; Hama, T.; Masuda, H.; Horie, S. Combined inhibitory effects of soy isoflavones and curcumin on the production of prostate-specific antigen. Prostate 2010, 70, 1127-1133. [CrossRef] [PubMed]

201. Carroll, R.E.; Benya, R.V.; Turgeon, D.K.; Vareed, S.; Neuman, M.; Rodriguez, L.; Kakarala, M.; Carpenter, P.M.; McLaren, C.; Meyskens, F.J.; et al. Phase IIa clinical trial of curcumin for the prevention of colorectal neoplasia. Cancer Prev. Res. 2011, 4, 354-364. [CrossRef] [PubMed]

202. He, Z.Y.; Shi, C.B.; Wen, H.; Li, F.L.; Wang, B.L.; Wang, J. Upregulation of p53 expression in patients with colorectal cancer by administration of curcumin. Cancer Investig. 2011, 29, 208-213. [CrossRef] [PubMed]

(C) 2016 by the authors; licensee MDPI, Basel, Switzerland. This article is an open access article distributed under the terms and conditions of the Creative Commons Attribution (CC-BY) license (http://creativecommons.org/licenses/by/4.0/). 